\title{
Peroxy radical partitioning during the AMMA radical intercomparison exercise
} \author{
A. E. Parker ${ }^{4}$ \\ ${ }^{1}$ Institute of Environmental Physics, University of Bremen, Bremen, Germany \\ ${ }^{2}$ School of Chemistry, University of Leeds, Leeds, UK \\ ${ }^{3}$ School of Earth and Environment, University of Leeds, Leeds, UK \\ ${ }^{4}$ Department of Chemistry, University of Leicester, Leicester, UK \\ ${ }^{5}$ School of Environmental Sciences, University of East Anglia, Norwich, UK \\ ${ }^{6}$ Institute of Atmospheric Physics, Deutsches Zentrum für Luft- und Raumfahrt (DLR), \\ Oberpfaffenhofen, Germany \\ ${ }^{7}$ National Centre for Atmospheric Science, University of Leeds, Leeds, UK \\ ${ }^{8}$ Department of Meteorology, University of Reading, Reading, UK \\ *now at: School of Engineering and Applied Science, Harvard University, Cambridge, USA
}

M. D. Andrés-Hernández ${ }^{1}$, D. Stone ${ }^{2,3}$, D. M. Brookes ${ }^{4}$, R. Commane ${ }^{2, *}$, C. E. Reeves ${ }^{5}$, H. Huntrieser ${ }^{6}$, D. E. Heard ${ }^{2,7}$, P. S. Monks ${ }^{4}$, J. P. Burrows ${ }^{1}$, H. Schlager ${ }^{6}$, D. Kartal ${ }^{1}$, M. J. Evans ${ }^{3}$, C. F. A. Floquet ${ }^{2}$, T. Ingham ${ }^{2,7}$, J. Methven ${ }^{8}$, and

Received: 11 February 2010 - Published in Atmos. Chem. Phys. Discuss.: 1 April 2010

Revised: 8 October 2010 - Accepted: 4 November 2010 - Published: 11 November 2010

\begin{abstract}
Peroxy radicals were measured onboard two scientific aircrafts during the AMMA (African Monsoon Multidisciplinary Analysis) campaign in summer 2006. This paper reports results from the flight on 16 August 2006 during which measurements of $\mathrm{HO}_{2}$ by laser induced fluorescence spectroscopy at low pressure (LIF-FAGE) and total peroxy radicals $\left(\mathrm{RO}_{2}^{*}=\mathrm{HO}_{2}+\Sigma \mathrm{RO}_{2}, \mathrm{R}=\right.$ organic chain $)$ by two similar instruments based on the peroxy radical chemical amplification (PeRCA) technique were subject of a blind intercomparison. The German DLR-Falcon and the British FAAM-BAe-146 flew wing tip to wing tip for about $30 \mathrm{~min}$ making concurrent measurements on 2 horizontal level runs at 697 and $485 \mathrm{hPa}$ over the same geographical area in Burkina Faso. A full set of supporting measurements comprising photolysis frequencies, and relevant trace gases like $\mathrm{CO}, \mathrm{NO}$, $\mathrm{NO}_{2}, \mathrm{NO}_{\mathrm{y}}, \mathrm{O}_{3}$ and a wider range of VOCs were collected simultaneously.

Results are discussed on the basis of the characteristics and limitations of the different instruments used. Generally, no data bias are identified and the $\mathrm{RO}_{2}^{*}$ data available agree quite reasonably within the instrumental errors. The $\left[\mathrm{RO}_{2}^{*}\right] /\left[\mathrm{HO}_{2}\right]$ ratios, which vary between 1:1 and 3:1, as well as the peroxy
\end{abstract}

Correspondence to:

M. D. Andrés-Hernández

(lola@iup.physik.uni-bremen.de) radical variability, concur with variations in photolysis rates and in other potential radical precursors. Model results provide additional information about dominant radical formation and loss processes.

\section{Introduction}

Hydroperoxy- $\left(\mathrm{HO}_{2}\right)$ and alkyl peroxy $\left(\mathrm{RO}_{2} ; \mathrm{R}=\right.$ organic chain) radicals are involved in many of the oxidation mechanisms taking place in the troposphere. They are short lived species originating from the oxidation of carbon monoxide (CO) and volatile organic compounds (VOCs) (Monks, 2005). Their reactions are closely coupled with those of the most important atmospheric oxidative agent, the hydroxyl radical $\mathrm{OH}$, and the formation mechanisms of chemically or toxicologically important pollutants like ozone $\left(\mathrm{O}_{3}\right)$, peroxy acetyl nitrate (PAN), aldehydes, acids, etc. Knowledge of the atmospheric radical content and radical distribution provides essential information about the oxidative state of an air mass. In spite of their importance in the chemical processing of the troposphere, only a very limited number of airborne peroxy radical measurements are available (Brune et al., 1998; Jaeglé et al., 2001; Hanke et al., 2002; Cantrell et al., 2003a, b; Martinez et al., 2008). In particular, there are no previous measurements in or over Africa.

Published by Copernicus Publications on behalf of the European Geosciences Union. 
Within the European Project AMMA (African Monsoon Multidisciplinary Analysis) the fast photochemical processing during the West African Monsoon (WAM) period was investigated. Overall the AMMA project aims to improve the knowledge about the WAM variability and the impact on the local and global atmospheric composition. One of the main scientific objectives was to investigate the development of Mesoscale Convective Systems (MCS), including their impact on the transport of trace gases. For this, 5 different instrumented aircrafts were deployed within AMMA covering the measurement of trace gases over a broad vertical and horizontal area (Reeves et al., 2010). The importance of convection in determining the abundance of radical precursors in the Upper Troposphere (UT) has recently been confirmed experimentally within AMMA by Bechara et al. (2009), who measured enhancement of isoprene and other VOCs up to $10 \mathrm{~km}$ altitude within MCS episodes. Some of the products of isoprene oxidation have lifetimes of several hours, and it is possible that such compounds, as well as brominated and iodinated hydrocarbons, are locally transported to the UT by convective activity. Peroxy radical observations made within AMMA (Andrés-Hernández et al., 2009) are indicative of enhanced in situ production of peroxy radicals in the upper troposphere during convective episodes, linking the boundary layer, free troposphere and UT/LS chemistry.

The general interpretation of the impact of radical chemistry relies consequently on the data quality control designed to prevent any misinterpretation of results derived from offsets or other kind of instrumental artefacts. The intercalibration of similar instruments is a crucial part of the data analysis and interpretation, and the results obtained can be used to provide an estimate of the uncertainty associated with the airborne measurement of radicals. As reported by Reeves et al. (2010) wing tip to wing tip comparison flights along straight and level runs at various altitudes were performed during AMMA. The present work focuses on the comparison and evaluation of peroxy radical measurements.

\section{Experimental description}

Three instruments for the measurement of peroxy radicals participated in the intercomparison exercise which took place on the 16 August 2006. Figure 1 depicts the corresponding flight track over the MSG (Meteosat Second Generation) satellite image at $15: 00 \mathrm{~h}$ with IR brightness temperature. These images were usually used to locate the MCS during AMMA. The German DLR-Falcon (hereafter referred to as D-Falcon) and the British FAAM-BAe-146 (hereafter referred to as BAe-146) flew wing tip to wing tip for approximately $30 \mathrm{~min}$, first in a straight and level westward run at $697 \mathrm{hPa}$ followed by a straight and level eastward run at $485 \mathrm{hPa}$ over the same geographical area in Burkina Faso. More details of the intercomparison including the results for measurements of $\mathrm{CO}, \mathrm{O}_{3}, \mathrm{CO}_{2}, \mathrm{HCHO}$ and $\mathrm{NO}_{\mathrm{y}}$ are given

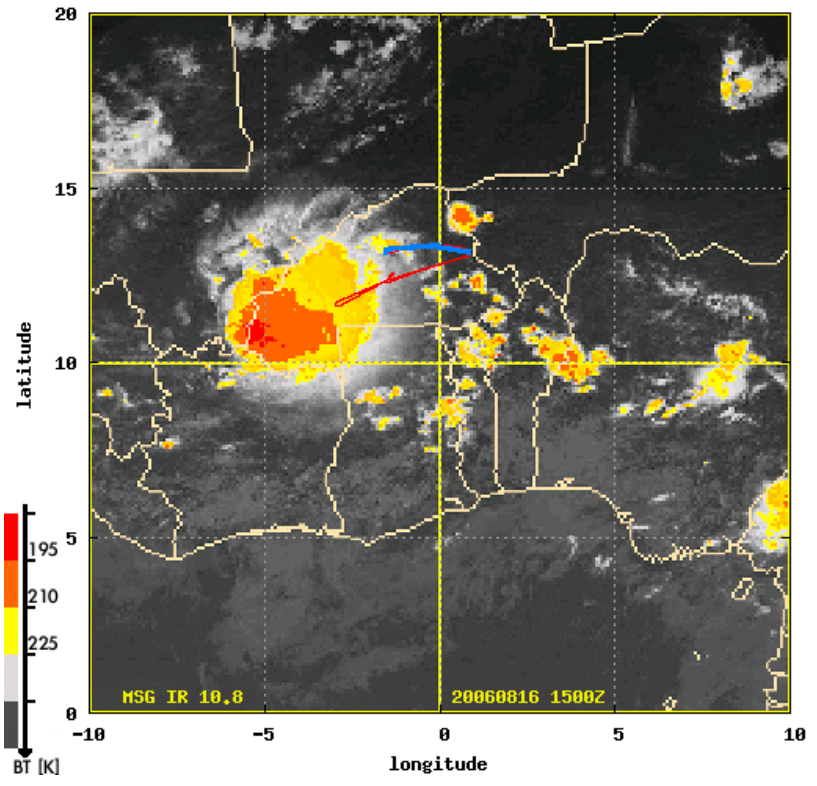

Fig. 1. Flight track on 16 August 2006. The part corresponding with the AMMA intercomparison exercise is highlighted in blue and was from 15:00 to $15: 50$ whilst the Meteosat infrared image is from 15:00 UTC.

in Reeves et al. (2010). Results of the initial CO comparison led to a comparison of standards which showed that the data for the D-Falcon and BAe-146 should be corrected by a factor of 0.997 and 1.069 , respectively.

Table 1 summarises the instrumentation in both aircrafts used for the present data analysis. A more detailed description of individual instruments is included in the following sections

\subsection{Peroxy Radical Chemical Amplification}

The Peroxy Radical Chemical Amplification technique (PeRCA) utilises the amplified conversion of the peroxy radicals entering the reactor into $\mathrm{NO}_{2}$ in a chain reaction involving $\mathrm{NO}$ and $\mathrm{CO}$, namely:

$$
\begin{aligned}
& \mathrm{HO}_{2}+\mathrm{NO} \longrightarrow \mathrm{NO}_{2}+\mathrm{OH} \\
& \mathrm{OH}+\mathrm{CO}+\mathrm{O}_{2} \stackrel{\mathrm{M}}{\longrightarrow} \mathrm{CO}_{2}+\mathrm{HO}_{2} \\
& \mathrm{RO}_{2}+\mathrm{NO} \longrightarrow \mathrm{NO}_{2}+\mathrm{RO} \\
& \mathrm{RO}+\mathrm{O}_{2} \longrightarrow \mathrm{HO}_{2}+\text { organic products }
\end{aligned}
$$

By switching the addition of the reagent $\mathrm{CO}$ with an identical flow of $\mathrm{N}_{2}$ between the front and back of the reactor the chain chemistry is modulated between chain amplification mode (i.e., $\mathrm{NO}_{2}$ from the conversion of peroxy radicals plus other background trace gases producing $\mathrm{NO}_{2}$ in their reaction with $\mathrm{NO}$ like $\mathrm{O}_{3}$, plus $\mathrm{NO}_{2}$ itself) and background measurement mode (i.e., $\mathrm{NO}_{2}$ comprising that in outside air plus 
Table 1. Summary of the measurement techniques deployed during the AMMA peroxy radical intercomparison exercise, $\left[\mathrm{RO}_{2}^{*}\right]=\left(\left[\mathrm{HO}_{2}\right]+\Sigma\left[\mathrm{RO}_{2}\right]\right)$; dl: detection limit.

\begin{tabular}{|c|c|c|c|c|c|}
\hline $\begin{array}{l}\text { Instrument/ } \\
\text { Aircraft }\end{array}$ & Technique & Measurement & Institution & $\begin{array}{l}\text { Time } \\
\text { resolution }\end{array}$ & Special features \\
\hline $\begin{array}{l}\text { DUALER/ } \\
\text { D-Falcon }\end{array}$ & PeRCA & {$\left[\mathrm{RO}_{2}^{*}\right]$} & IUP-UB & $\begin{array}{l}1 \mathrm{~s}, 60 \mathrm{~s} \\
\text { reported }\end{array}$ & $\begin{array}{l}\text { Dual inlet, } \\
\mathrm{P} \text { controlled, }_{\mathrm{HO}_{2} \text { calibration }}\end{array}$ \\
\hline $\begin{array}{l}\text { PeRCA 4/ } \\
\text { BAe-146 }\end{array}$ & PeRCA & {$\left[\mathrm{RO}_{2}^{*}\right]$} & $\begin{array}{l}\text { University } \\
\text { of Leicester }\end{array}$ & $\begin{array}{l}1 \mathrm{~s}, 60 \mathrm{~s} \\
\text { avg }\end{array}$ & $\begin{array}{l}\text { Dual inlet, } \\
\mathrm{CH}_{3} \mathrm{O}_{2} \text { calibration }\end{array}$ \\
\hline BAe-146 & FAGE & $\begin{array}{l}\mathrm{HO}_{2} \text { by } \\
\text { titration to } \mathrm{OH}\end{array}$ & $\begin{array}{l}\text { University } \\
\text { of Leeds }\end{array}$ & $\begin{array}{l}1 \mathrm{~s}, 60 \mathrm{~s} \\
\text { reported }\end{array}$ & Commane et al., 2010 \\
\hline $\begin{array}{l}\text { UV } \\
\text { photometer/ } \\
\text { D-Falcon }\end{array}$ & UV absorption & $\mathrm{O}_{3}$ & DLR & $\begin{array}{l}1 \mathrm{~s}, 5 \% \\
\text { accuracy }\end{array}$ & $\mathrm{dl}: 1 \mathrm{ppb}$ \\
\hline $\begin{array}{l}\text { Aerolaser } \\
\text { AL5002/ } \\
\text { D-Falcon }\end{array}$ & $\begin{array}{l}\text { VUV } \\
\text { fluorescence }\end{array}$ & $\mathrm{CO}$ & DLR & $\begin{array}{l}1 \mathrm{~s}, 3 \% \\
\text { accuracy }\end{array}$ & $\mathrm{dl}: 1 \mathrm{ppb}$ \\
\hline $\begin{array}{l}\text { NR-IR } \\
\text { photometer/ } \\
\text { D-Falcon }\end{array}$ & IR absorption & $\mathrm{CO}_{2}$ & DLR & $\begin{array}{l}1 \mathrm{~s}, 0.3 \mathrm{ppm} \\
\text { accuracy }\end{array}$ & $\mathrm{dl}: 0.1 \mathrm{ppm}$ \\
\hline $\begin{array}{l}\text { Whole Air } \\
\text { Samples } \\
\text { (WAS)/ } \\
\text { BAe-146 }\end{array}$ & $\begin{array}{l}\text { off line analysis } \\
\text { with dual channel } \\
\text { GC }\end{array}$ & VOCs & $\begin{array}{l}\text { University } \\
\text { of York }\end{array}$ & $15 \mathrm{~min}$ & Grab samples \\
\hline $\begin{array}{l}\mathrm{NO}_{\mathrm{x}}-\mathrm{NO}_{\mathrm{y}} / \\
\mathrm{D}-\text { Falcon }\end{array}$ & $\begin{array}{l}\text { Phot. convert- } \mathrm{NO}_{2} \\
\mathrm{Au}-\text { convertor-NO } \\
\text { Chemilumin. (NO) }\end{array}$ & $\mathrm{NO}_{\mathrm{y}}, \mathrm{NO}$ & DLR & $1 \mathrm{~s}$ & $\begin{array}{l}\text { dl: } 5 \text { pptv (NO) } \\
15 \text { pptv }\left(\mathrm{NO}_{\mathrm{y}}\right)\end{array}$ \\
\hline /BAe-146 & $\begin{array}{l}\text { Gas } \\
\text { Chromatography }\end{array}$ & PAN & $\begin{array}{l}\text { University } \\
\text { of Leeds }\end{array}$ & $90 \mathrm{~s}$ & \\
\hline $\begin{array}{l}\text { YES, Inc, } \\
\text { AL4021/ } \\
\text { D-Falcon }\end{array}$ & $\begin{array}{l}\text { Hantzsch } \\
\text { technique, } \\
\text { Fluorometry }\end{array}$ & $\mathrm{HCHO}$ & DLR & $\begin{array}{l}60 \mathrm{~s}, 15 \% \\
\text { accuracy }\end{array}$ & $\mathrm{dl}<50 \mathrm{pptv}$ \\
\hline $\begin{array}{l}\text { Ionico } \\
\text { Analytik/ } \\
\text { BAe-146 }\end{array}$ & $\begin{array}{l}\text { Proton Transfer } \\
\text { Mass } \\
\text { Spectrometer } \\
\text { (PTR-MS) }\end{array}$ & $\begin{array}{l}\text { Real-time } \\
\text { Oxygenates }\end{array}$ & $\begin{array}{l}\text { University } \\
\text { of East } \\
\text { Anglia }\end{array}$ & $1-2 \mathrm{~s}$ & Every $15 \mathrm{~s}$ \\
\hline /BAe-146 & Filter radiometry & $j\left(\mathrm{NO}_{2}\right)$ & $\begin{array}{l}\text { University } \\
\text { of Leicester }\end{array}$ & $1 \mathrm{~s}$ & $4 \pi \mathrm{sr}$ \\
\hline /BAe-146 & Filter radiometry & $j\left(\mathrm{O}^{1} \mathrm{D}\right)$ & $\begin{array}{l}\text { University } \\
\text { of Leicester }\end{array}$ & $1 \mathrm{~s}$ & $4 \pi \mathrm{sr}$ \\
\hline /D-Falcon & Filter radiometry & $j\left(\mathrm{NO}_{2}\right)$ & DLR & $1 \mathrm{~s}$ & $4 \pi \mathrm{sr}$ \\
\hline
\end{tabular}

other background trace gases producing $\mathrm{NO}_{2}$ in their reaction with NO). NO is added continuously at the front of the reactor, such that in amplification mode $\mathrm{NO}$ and $\mathrm{CO}$ are added together and $\mathrm{N}_{2}$ is added at the back, while in background mode $\mathrm{NO}$ and $\mathrm{N}_{2}$ are added together with $\mathrm{CO}$ added at the back. This methodology maintains the overall properties of the reagent mixture in the sample airflow downstream of the reactor and reduces pressure pulsing on switching measurement modes.
The chemiluminescence of the reaction of $\mathrm{NO}_{2}$ with luminol (3-aminophthalhydrazide: $\mathrm{C}_{8} \mathrm{H}_{7} \mathrm{~N}_{3} \mathrm{O}_{2}$ ) is used to measure the $\mathrm{NO}_{2}$. The amount of peroxy radicals is calculated from the difference between the signals in both modes, $\Delta \mathrm{NO}_{2}$, and the knowledge of the amplification factor or chain length $(\mathrm{CL})$ and radical loss at the inlet. PeRCA measures the total sum of $\mathrm{RO}, \mathrm{OH}, \mathrm{HO}_{2}$ and $\mathrm{RO}_{2}$ radicals. As $\Sigma\left[\mathrm{RO}_{2}\right] \gg \Sigma[\mathrm{RO}]$ and $\left[\mathrm{HO}_{2}\right] \gg[\mathrm{OH}]$ in the troposphere, the measured signal is a good approximation of the total sum of peroxy radicals $\left(\mathrm{RO}_{2}^{*}=\mathrm{HO}_{2}+\Sigma \mathrm{RO}_{2}\right)$. 
The CL depends on humidity (Mihele and Hastie, 1998; Mihele et al., 1999; Salisbury et al., 2002; Reichert et al., 2003), residence time in and shape and material of the reactor, and on the ratio of the gases added for the chemical conversion, i.e., [NO]/[CO]. Instruments based on PeRCA have been developed for the airborne measurement of peroxy radicals (Green et al., 2003). In order to increase sensitivity and accuracy, dual systems comprising two identical reactors, which concurrently measure in the same or alternate modes, are coupled with one or two detectors (Cantrell et al., 1996; Green et al., 2006). Interferences related to short term variations of concentrations during the airborne sampling cycle are thereby minimized.

\subsubsection{DUALER (DUal channel $A$ irborne peroxy radica $L$ chemical amplifiER)}

As indicated in Table 1, the Institute of Environmental Physics of the University of Bremen (IUP-UB) participated in the wet monsoon measurement campaign of AMMA in August 2006 with the measurement of the total sum of peroxy radicals, $\mathrm{RO}_{2}^{*}$, onboard of the German D-Falcon using a DUALER.

The airborne DUALER deployed on the D-Falcon has been developed by IUP-UB from the first calibrated PeRCA (Hastie et al., 1990) which has been gradually improved and implemented in several campaigns and comparison exercises for ground based measurements (Zenker et al., 1998; Andrés Hernández et al., 2001; Burkert et al., 2001a, b, 2003). This instrument bases on the concept described in Sect. 2.2. for aircraft measurements. The IUP-UB DUALER utilises a common inlet, and comprises a double reactor $(21 \mathrm{~mm}$ ID, $310 \mathrm{~mm} \mathrm{~L}$ stainless steel cylinders, with a $10 \mathrm{~mm}$ inlet orifice) sampling from a common pre-reactor nozzle and connected to two identical luminol detectors. Three way valves in the inlet system are switched every $60 \mathrm{~s}$ and alternate the modes of the reactors. The DUALER is kept at a below ambient, constant fixed pressure during the measurement. The CL decreases with the pressure and the sensitivity of the instrument reaches a maximum for an operating pressure around 500 mbar. During the intercomparison exercise the DUALER was kept at 300 mbar. The characterisation, calibration procedures and performance during the measurement campaign are described in detail elsewhere (Kartal et al., 2010).

The known dependency of the $\mathrm{CL}$ on the relative humidity (RH) of the air sampled (Mihele and Hastie, 1998; Mihele et al., 1999; Reichert et al., 2003) has a negligible effect under the AMMA measurement conditions. The DUALER inlet is not heated during the AMMA flights but its inner part is connected to the cabin of the aircraft. As a consequence, the temperature of the reactors remains always higher than that of the outside air. Therefore, the $\mathrm{RH}$, being $\mathrm{RH}=\left(P_{\text {partial }}^{\mathrm{H}_{2} \mathrm{O}} / P_{\text {saturation }}^{\mathrm{H}_{2} \mathrm{O}}\right)$, decreases in the reac- tors respect to the ambient as $T_{\text {ambient }}<T_{\text {reactor }}$ causes the increase in $P_{\text {saturation }}^{\mathrm{H}_{2} \mathrm{O}}$, and $P_{\text {ambient }}>P_{\text {reactor }}$ causes the decrease in the $P_{\text {partial }}^{\mathrm{H}_{2} \mathrm{O}}$ in the reactors (Kartal, 2009). The in flight detection limit and accuracy of the instrument depend on the stability of the luminol flow, the variability of the air mass composition sampled and the operating pressure. For most of the AMMA airborne measurements the relative accuracy was between 25 and $45 \%$ and the $\mathrm{RO}_{2}^{*}$ detection limit varied between 2 and 5 pptv for a $20 \mathrm{~s}$ time resolution (Kartal et al., 2009). During the intercomparison exercise the decrease in the $\mathrm{RH}$ relative to the ambient was dominated by the decrease in the $P_{\text {partial }}^{\mathrm{H}_{2} \mathrm{O}}$ as the DUALER operated at $300 \mathrm{mbar}$. The $\mathrm{RH}$ in the reactors remained below $15 \%$. At $300 \mathrm{mbar}$ this effect in the CL is expected to be within the error of the CL determination.

\subsubsection{PeRCA 4}

The University of Leicester airborne PeRCA instrument (designated PeRCA 4) is a dual channel (two inlet, two detector) PeRCA and was operated on board the BAe-146 during AMMA. The PeRCA 4 instrument was originally designed and built jointly between the University of Leicester and the University of East Anglia. The application of the PeRCA 4 dual channel system to ground based measurements was first described by Green et al. (2006). The aircraft instrument, its characterisation, calibration procedures and performance during the measurement campaign are detailed in Brookes (2009).

PeRCA 4 uses two equivalent channels each comprising a low-volume pyrex inlet coupled to a modified LMA-3 Scintrex $\mathrm{NO}_{2}$ detector channel. A sample flow of $2 \mathrm{slpm}$ is drawn through each inlet inclusive of ambient air and reagent gases. In each inlet the chain chemistry described in Sect. 2.1 is modulated between chain amplification mode and background measurement mode by switching the addition of a flow of the reagent $\mathrm{CO}(100 \mathrm{sccm}, 5 \% / \mathrm{vol}$. equivalent in the sample flow) with an identical flow of $\mathrm{N}_{2}$ between the front and back of the inlet (typically every 60 s)while a flow of the reagent $\mathrm{NO}(10 \mathrm{sccm}, 3 \mathrm{ppmv}$ equivalent in the sample flow) is added continuously at the front of the inlet. Reagents and $\mathrm{N}_{2}$ are supplied under pressure from gas cylinders held within the instrument rack inside the aircraft cabin with flow control maintained using mass flow controllers (Tylan FC260, now manufactured and distributed by Celerity Inc.). Total sample flow is maintained at 2 slpm (1.79 slpm ambient air, 0.21 slpm reagent gases) by a combination of mass flow meters (MFM, Tylan FM360) in series with stepper motor controlled needle valves; active control of the stepper motors via computer software provides sample flows to within $\pm 50 \mathrm{sccm}$. A Leybold Sogevac SV16 oil filled rotary vacuum pump (capable of a pumping speed of $14.5 \mathrm{~m}^{3} \mathrm{~h}^{-1}$, down to a pressure of $80 \mathrm{mbar}$ ) provides suction to pull the sample air flow from the inlets through to the Scintrex detectors. 
a)

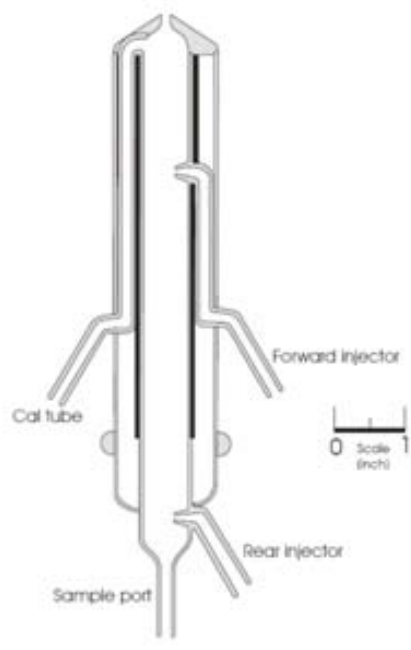

b)

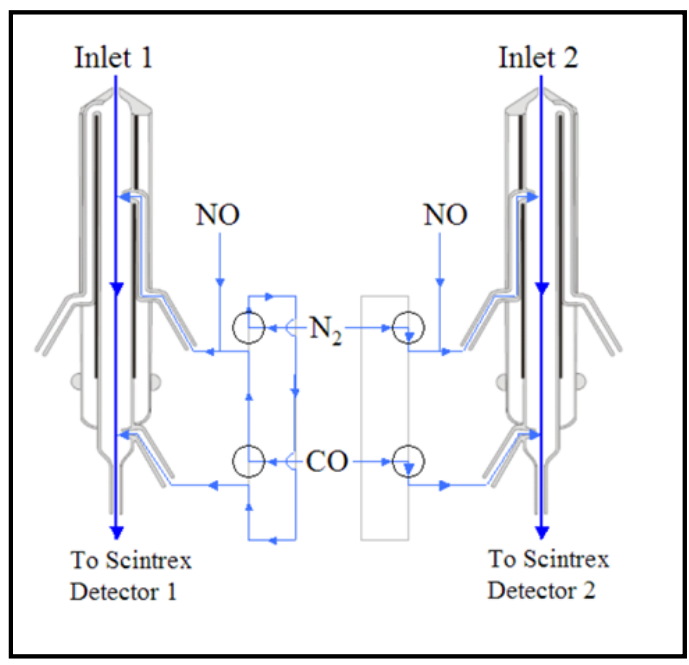

Fig. 2. (a) Scale diagram of aircraft inlet and (b) PeRCA 4 dual inlet scheme: Inlet 1 in chain amplification mode (NO and CO addition at front port, $\mathrm{N}_{2}$ at back), Inlet 2 in background measurement mode ( $\mathrm{NO}$ and $\mathrm{N}_{2}$ addition at front port, $\mathrm{CO}$ at back), arrows indicate direction of gas flow, circles indicate 2-way valves (from Brookes, 2009).

The channels are run out of phase as shown in Fig. 2, to provide simultaneous measurements of chain amplified and background $\mathrm{NO}_{2}$, and the radical chain amplified $\mathrm{NO}_{2}$ signal is determined by subtraction of the background measurement.

It was not possible to perform in flight CL calibrations on board the BAe-146, and consequently calibrations were performed at ground level in the laboratory following the AMMA campaign. The calibration procedure for the PeRCA 4 inlet chain lengths is based on the method of Clemitshaw et al. (1997), whereby known concentrations of methyl peroxy are generated through UV photolysis of methyl iodide. The calibration procedure as yet does not take into account the change in CL with temperature and pressure although it would be preferable to perform CL calibrations at different altitudes, to account for the temperature and pressure dependent rate constants of the chain chemistry reactions.

The PeRCA 4 inlets (Fig. 2) sample the airflow at ambient air pressure perpendicular to the aircraft direction of flight. The inlets can be heated to reduce the impact of humidity on the chain length, however this system fails in flight on the BAe-146. The result is that for the PeRCA 4 instrument the air temperature, pressure and humidity are expected to remain at ambient levels on sampling and impact on the chain length. A systematic reduction in the chain length with altitude has been modelled (Brookes, 2009) using the FACSIMILE package (v4.40.101, MCPA Software Ltd.) using an inlet chemistry reaction mechanism based on that of Hastie et al. 1991) and rate coefficients taken from the recommendations of Sander et al. (2006) and Atkinson et al. (2004, 2006). Pressure and temperature were constrained in the model using the pressure and temperature altitude profiles measured from the BAe-146 during AMMA, further details of the model setup can be found in Brookes (2009). At the altitude of the intercomparison level run where the PeRCA 4 operated (700 mbar) a reduction in the CL of the order $20 \%$ is modelled. The reduction of the PeRCA 4 chain length with altitude will contribute to systematic bias between the PeRCA 4 and DUALER measurements, where the DUALER reactor is pressure controlled and the PeRCA 4 chain length has not been corrected. The modelled variation in the CL at altitude $\left(\mathrm{CL}_{\mathrm{alt}}\right)$ relative to the $\mathrm{CL}$ at ground level $\left(\mathrm{CL}_{0}\right)$ is shown as a function of pressure in Fig. 3.

To correct for the humidity interference to the chain chemistry a correction function (dependent on relative humidity) was derived and applied to the AMMA PeRCA $4\left[\mathrm{RO}_{2}^{*}\right]$ dataset as demonstrated in Fig. 4. The model to measurement ratio as a function of temperature shows the humidity corrected data consistently over estimates the model with no real trend. A slight increasing trend with temperature is observed in the non humidity corrected model to measurement ratio. This has no relationship to humidity and in fact can be explained the changing composition of the radical population with altitude (Brookes, 2009). Model to measurement agreement improves at higher altitude (lower temperature) where the radical population is primarily composed of $\mathrm{HO}_{2}$ and $\mathrm{CH}_{3} \mathrm{O}_{2}$. At lower altitudes (higher temperature) a more complex population of organic peroxy radicals influenced by the surface emissions of isoprene is modelled and the increased model to measurement ratio reflects a reduced sensitivity of the measurement to these components of the radical population. 


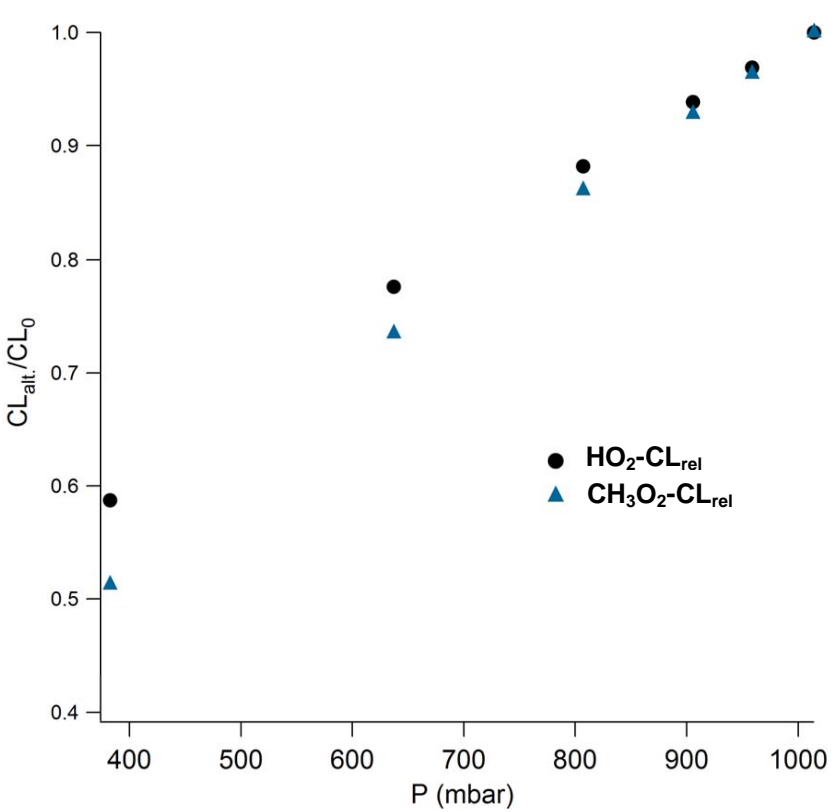

Fig. 3. Modelled variation in the PeRCA 4 chain length relative to ground level $\left(\mathrm{CL}_{0}\right)$ for $\mathrm{HO}_{2}$ and $\mathrm{CH}_{3} \mathrm{O}_{2}, \mathrm{CL}_{\text {alt. }}$ stands for $\mathrm{CL}$ at single altitude (Brookes, 2009).

On application of the correction to the AMMA dataset as whole the concentrations typically scaled on average by a factor of 4.4 resulting in up to several hundreds of pptv $\left[\mathrm{RO}_{2}^{*}\right]$ (Brookes, 2009); this scaling is considered unrealistic since concentrations this high have not been reported in the tropical troposphere. By comparison of the uncorrected PeRCA 4 $\left[\mathrm{RO}_{2}^{*}\right]$ dataset to output from the DSMACC model (Emmerson and Evans, 2009; Stone et al., 2010), the uncorrected data was assessed for any systematic bias with humidity (Brookes, 2009). The model to measurement ratio exhibits no trend with relative humidity. To apply the humidity correction to this dataset may therefore be inappropriate and the intercomparison was made using the uncorrected data.

The expected humidity bias in the measurement response was not observed in the PeRCA 4 AMMA dataset despite the consistently high humidity encountered during the monsoon season (Brookes, 2009), and thus a potential explanation is sought. Owing to their low thermal mass the PeRCA 4 inlets are expected to be in thermal equilibrium with the aircraft cabin and ambient airflow. A temperature gradient is also expected between the inlet tip in contact with the ambient airflow, and the inside in contact with the aircraft cabin. The most significant interaction between the inlet and the ambient airflow will occur on sampling and it is hypothesized that at this cold point water vapour may condense, thus reducing the relative humidity sampled. This hypothesis also provides an explanation of the observed loss of sample flow through the mechanism of inlet tip icing; the sample flow was observed to drop dramatically at altitudes above the freezing point in highly saturated conditions during AMMA (Brookes, 2009). Although the condensation of water vapour prior to the reaction zone may reduce the impact of humidity on the chain length, significant sampling losses of $\mathrm{HO}_{2}$ are expected (Brookes, 2009) as reported by Green et al. (2003). Systematic differences in the $\mathrm{RO}_{2}^{*}$ measurements may then be attributed to the relative sensitivity of the respective PeRCA instruments to inorganic and organic peroxy radicals.

The PeRCA 4 inlet chain lengths were calibrated following the AMMA campaign in reference to known concentrations of the methyl peroxy radical, for details see e.g. Green et al. (2003). The accuracy of the derived $\mathrm{RO}_{2}^{*}$ concentration will depend on the relative proportion of the radical population made up by the methyl peroxy radical and radicals with a similar effective chain length. The calibration procedure for the $\mathrm{NO}_{2}$ sensitivity of the LMA-3 Scintrex detectors is detailed in Brookes (2009). Ordinarily the LMA-3 detectors are calibrated by mixing the output from a VICI Metronics $\mathrm{NO}_{2}$ wafer permeation device with varying flows of zero air, but owing to technical problems with the calibration system on board the BAe-146, it was not possible to perform reliable in-flight calibrations. An alternative method was developed using the background signal on the LMA-3 detectors along with the in-situ ozone measurements made on board the BAe-146 with a commercial Thermo Environmental Instruments Inc. $49 \mathrm{C}$ ozone analyser. The relative levels of ozone and $\mathrm{NO}_{2}$ encountered during AMMA were such that the background signals measured on the LMA-3 detectors were almost entirely due to the oxidation of reagent $\mathrm{NO}$ by ozone with a negligible contribution from ambient $\mathrm{NO}_{2}$. The absolute $\mathrm{NO}_{2}$ background concentration generated from this reaction was derived using the temperature dependence of the reaction rate constant and the variation of the residence time with temperature and pressure. The derived background $\mathrm{NO}_{2}$ concentration within the sample flow was used to weight the detector response. Thus the $\mathrm{NO}_{2}$ sensitivity of the detectors was calculated along the flight track for every point during which ozone measurements were available.

The estimated accuracy of the PeRCA 4 measurements is of the order $40 \%$, not accounting for uncertainty introduced by variation in the CL by altitude and systematic differences introduced by the weighting of the response by the CL with respect to the methyl peroxy radical. The average detection limit of the PeRCA 4 dual channel measurement over the intercomparison run at $697 \mathrm{hPa}$ is $10.4 \mathrm{pptv}$ for a $60 \mathrm{~s}$ averaging interval.

\subsection{Fluorescence Assay by Gas Expansion (FAGE)}

Fluorescence Assay by Gas Expansion (FAGE) is a low pressure laser-induced fluorescence technique used for the detection of $\mathrm{OH}$ and $\mathrm{HO}_{2}$. The instrument and associated calibrations are described in detail in Commane et al. (2010) and only a brief overview will be presented here. During 
a)
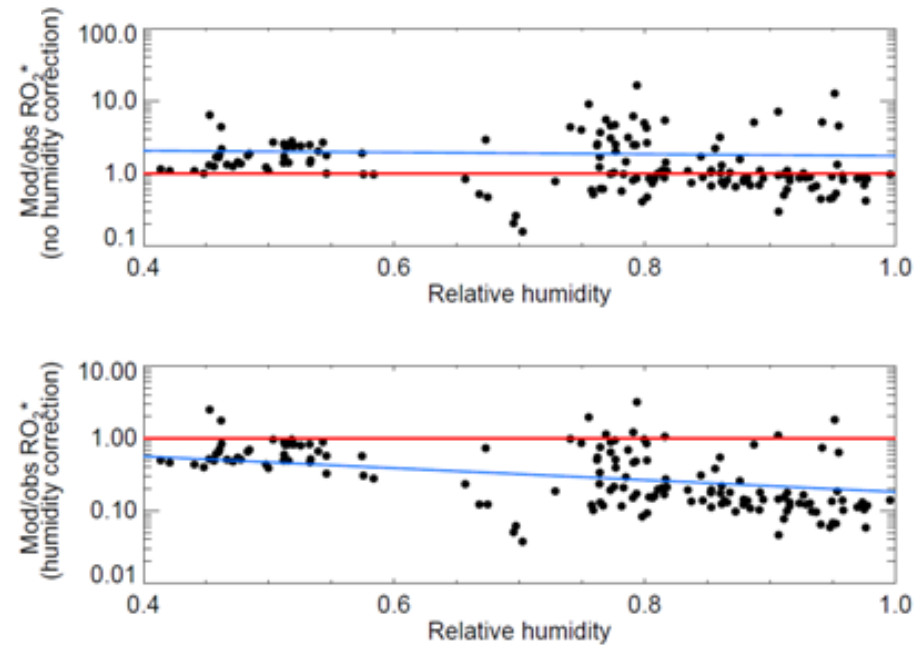

b)
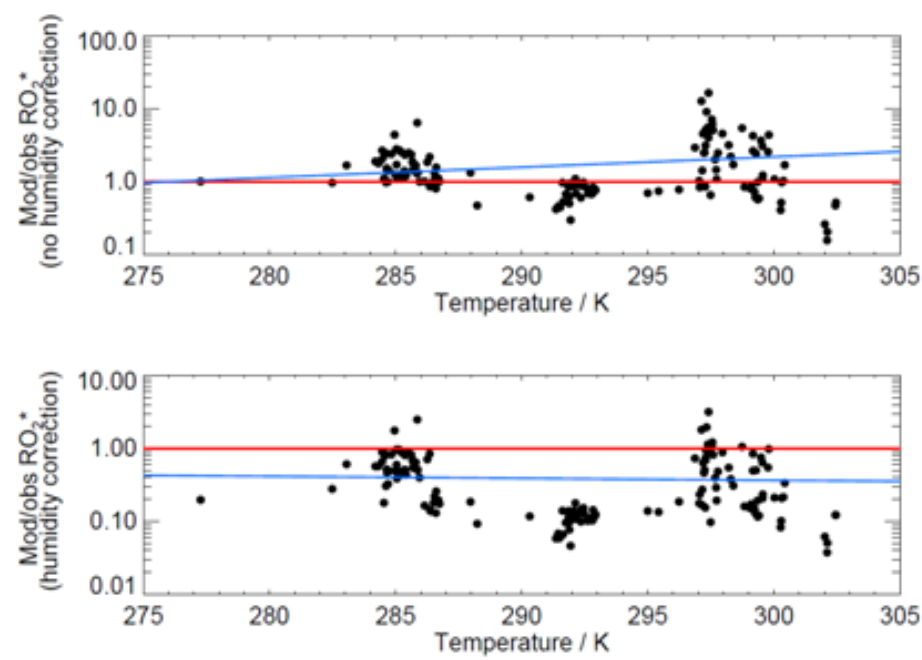

Fig. 4. DSMACC model to PeRCA 4 measurement ratio as a function of relative humidity (as a fraction).

the intercomparison flight described here, only $\mathrm{HO}_{2}$ was observed. $\mathrm{OH}$ was not observed due to technical problems during the period of the campaign.

In this instrument $\mathrm{HO}_{2}$ is titrated to $\mathrm{OH}$ by the addition of pure NO $(99.999 \%)$. Air was sampled from a side-mounted inlet through a $0.75 \mathrm{~mm}$ pinhole into the fluorescence cell. A $\mathrm{Nd}$ :YAG pumped Ti:Sapphire laser is used to generate light at $\lambda \approx 308 \mathrm{~nm}$ in order to excite the Q1(2) transition of the $\mathrm{OH}$ molecule. The exact excitation wavelength is determined using a reference cell. The subsequent fluorescence of the $\mathrm{OH}$ molecule is also detected at $\lambda \approx 308 \mathrm{~nm}$. Maintaining the fluorescence cell at low pressure (1.5-2.5 Torr) allows for temporal gating of the fluorescence detection. The sensitivity of the instrument to $\mathrm{HO}_{2}$ was determined by calibration before and after the campaign. In these calibrations, a known concentration of $\mathrm{HO}_{2}$ is produced by the photolysis of water vapour (at $\lambda=184.9 \mathrm{~nm}$ ) in a turbulent flow of air. The $\mathrm{HO}_{2}$ data was collected at $1 \mathrm{~Hz}$ and averaged to $60 \mathrm{~s}$ for comparison here. The mean limit of detection of the instrument for the data discussed here is $0.31 \mathrm{pptv}(60 \mathrm{~s}$ integration time).The total uncertainty of the measurement is $26 \%$ at $2 \sigma$.

\subsection{Further instrumentation}

A complete description of the aircraft instrumentation during AMMA can be found elsewhere (Reeves et al., 2010). For the data analysis of the present work, $\mathrm{O}_{3}, \mathrm{CO}_{2}, \mathrm{CO}, \mathrm{HCHO}$ and reactive organic compounds measured on board the DFalcon by using respectively UV absorption (Schlager et al., 1997), IR absorption (Schulte et al., 1997), UV fluorescence (Gerbig et al., 1996), a fluorometric technique (Hantzsch reaction), and two $\mathrm{O}_{3} / \mathrm{NO}$-chemiluminescence detectors and a gold converter for reduction of higher oxidized $\mathrm{NO}_{\mathrm{y}}$ compouds to NO (Schlager et al., 1997; Ziereis et al., 2000) 
were used. The $\mathrm{NO}_{\mathrm{x}}$ was also measured by the UEA $\mathrm{NO}_{\mathrm{xy}}$ instrument on the BAe-146 that thermally converts $\mathrm{NO}_{\mathrm{y}}$ to $\mathrm{NO}_{2}$, using a gold convertor, photolytically converts $\mathrm{NO}_{2}$ to $\mathrm{NO}$ and measures NO by chemiluminescence (Brough et al., 2003; Stewart et al., 2008). The instrument has detection limits of 3,15 and $10 \mathrm{pptv}$ and precisions of 10,30 and $21 \%$ for $\mathrm{NO}, \mathrm{NO}_{2}$ and $\mathrm{NO}_{\mathrm{y}}$, respectively.

Information regarding VOCs comes from the $15 \mathrm{~min}$ whole air samples (WAS) on board the BAe-146 which were analysed on the ground by dual-channel gas chromatography and flame ionization detection (Hopkins et al., 2003). The VOC detection limits and precisions varied from 1-10 pptv and $1-3 \%$, respectively, depending on compound. Isoprene, acetone and the sum of methyl vinyl ketone (MVK) and methacrolein (MACR) were also measured by proton mass transfer mass spectrometry (PTR-MS) at a higher time resolution and frequency (Table 1), but with detection limits of $20-80$ pptv and $10 \%$ precision. PAN was measured by gas chromatography (30 pptv detection limit and $3 \%$ precision).

$\mathrm{O}_{3}$ and $\mathrm{NO}_{2}$ photolysis frequencies $\left(j\left(\mathrm{O}^{1} \mathrm{D}\right)\right.$ and $\left.j\left(\mathrm{NO}_{2}\right)\right)$ were measured on board the BAe-146 using $4 \pi$ sr filter radiometers (see Table 1). A $4 \pi \mathrm{sr} j\left(\mathrm{NO}_{2}\right)$ radiometer (Meteorology Consult, $\mathrm{GmbH}$, Glasshütten, $10 \%$ accuracy) was also used on board the D-Falcon.

\section{Supporting calculations or modelling}

Model calculations have been made using the Dynamically Simple Model of Atmospheric Chemical Complexity (DSMACC) (Emmerson and Evans, 2009; Stone et al., 2010). DSMACC is a zero-dimensional box model using the Kinetic Pre-Processor (KPP) (Sandu et al., 2006), constrained to observations of long-lived species with a chemistry scheme generated by the Master Chemical Mechanism (MCM) (Saunders et al., 2003).

A full description of the model calculations undertaken for the AMMA campaign can be found in Stone et al. (2010). To be modelled, time points needed to have observations of $\mathrm{HO}_{2}$ or $\mathrm{RO}_{2}$ together with the physical state (latitude, longitude, pressure, temperature and water vapour) and observations of $\mathrm{CO}, \mathrm{O}_{3}, \mathrm{NO}, j\left(\mathrm{O}^{1} \mathrm{D}\right)$ and $j\left(\mathrm{NO}_{2}\right)$.

Observations of ethane, propane, iso-butane, $n$-butane, ethene, propene, acetylene, methanol, ethanol, acetone, formaldehyde, PAN, methyl ethyl ketone (MEK), isoprene, MVK and MACR were also included where available and kept constant at the observed value. All observations used as input to the model were made on the BAe-146. There was virtually no difference in the model output when including benzene and toluene measured on the BAe-146 in test runs. The results indicate that for a set of reactive species the model is relatively insensitive and the model covers the dominant radical production and loss processes.

Concentrations of methane and hydrogen were kept constant at values of $1770 \mathrm{ppmv}$ and $550 \mathrm{ppmv}$, respectively.
Where observations of alkanes and alkenes were not available, concentrations were estimated as a linear function of the $\mathrm{CO}$ concentration (Stone et al., 2010).

For each time point, those species which have not been observed are set initially to zero. Those species which have been observed are set to the observed value and kept constant. However, concentrations of oxides are nitrogen are treated differently to other species in the model. For each time point during a day the concentration of $\mathrm{NO}_{\mathrm{y}}$ (defined as $\mathrm{NO}+\mathrm{NO}_{2}+\mathrm{NO}_{3}+2 \mathrm{~N}_{2} \mathrm{O}_{5}+\mathrm{HONO}+\mathrm{HNO}_{4}$ ) is corrected so that the total $\mathrm{NO}_{\mathrm{y}}$ concentration is kept constant, but the concentration of the $\mathrm{NO}_{\mathrm{y}}$ species varies owing to changes in photolysis rates etc. At the end of each day the calculated concentration of one of the $\mathrm{NO}_{\mathrm{y}}$ species (typically either $\mathrm{NO}$ or $\mathrm{NO}_{2}$ ) is compared to the equivalent measured concentration and the concentration of all $\mathrm{NO}_{\mathrm{y}}$ species is fractionally increased or decreased so that the measured and the modelled concentrations of the observed species match.

Photolysis rates in the model are calculated from the Tropospheric Ultraviolet- Visible Model (TUV; http://cprm.acd. ucar.edu/Models/TUV/), assuming a constant ozone column of 260 Dobson units and an albedo of 0.1. Cloud correction factors for all reactions other than $\mathrm{O}_{3} \rightarrow \mathrm{O}\left({ }^{1} \mathrm{D}\right)+\mathrm{O}_{2}$ are calculated from the ratio of observed to simulated $j\left(\mathrm{NO}_{2}\right)$, with the cloud correction factor for $\mathrm{O}_{3} \rightarrow \mathrm{O}\left({ }^{1} \mathrm{D}\right)+\mathrm{O}_{2}$ calculated from the ratio of observed to simulated $j\left(\mathrm{O}^{1} \mathrm{D}\right)$.

A removal reaction was included for all species which can be considered as a continuous deposition process (such as dry deposition or continuous wet deposition). The deposition lifetime was initially set at $24 \mathrm{~h}$ and the sensitivity investigated.

For each observation of $\mathrm{HO}_{2}$ or $\mathrm{RO}_{2}$ the objective is to calculate an expected value from the other parameters measured on board the aircraft and the chemical scheme used. All aircraft parameters have been merged onto a $60 \mathrm{~s}$ timebase for expediency. The model is integrated forward in time with diurnally varying photolysis rates until a steady state is reached when the fractional difference in mean species concentration between a day and the previous day is less than 0.01. Full details can be found in Stone et al. (2010).

\section{Discussion of results}

Figure 5 shows the peroxy radicals measured by the DUALER, PeRCA $4\left(\mathrm{RO}_{2}^{*}\right)$ and FAGE $\left(\mathrm{HO}_{2}\right)$ at the two pressure levels of the intercomparison exercise. As explained in Sect. 2.2.2, a relative humidity correction was applied to the PeRCA 4 data set $\left[\mathrm{RO}_{2}{ }^{*}\right.$-PeRCA 4$]$ but this lead to spuriously high concentrations. Figure 6 illustrates the loss in PeRCA 4 sample flow during the intercomparison flight. With the aircraft ascending to higher altitude the temperature falls below freezing and simultaneously the water content changes from a mixed phase to condensed water (ice) only, as indicated by the Nevzorov probe data from the BAe-146. 


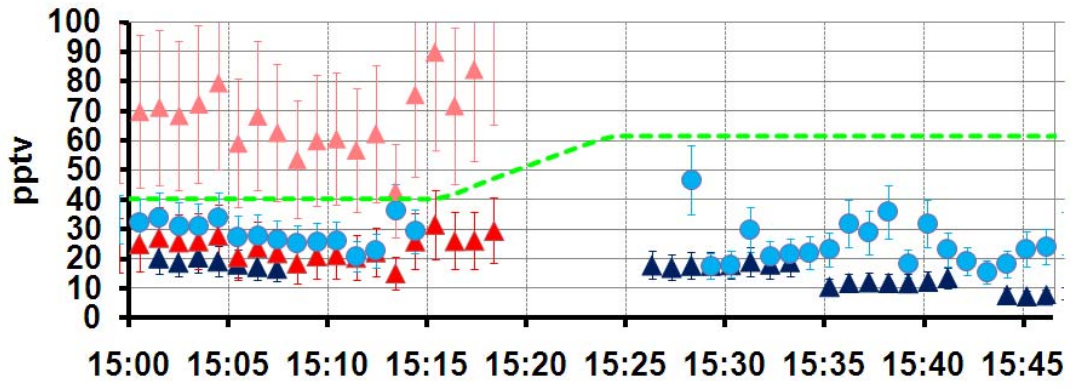

Fig. 5. Peroxy radicals measured during the AMMA intercomparison exercise. The pressure at the two measurement levels is indicated in green. $\mathrm{RO}_{2}^{*}-\mathrm{BAe}_{\text {corr }}$ are the $\left[\mathrm{RO}_{2}^{*}\right]$ obtained by applying the relative humidity correction of the CL to the PeRCA 4 instrument. [RO 2 -DF] are the $\left[\mathrm{RO}_{2}^{*}\right.$-DUALER] measured at the D-Falcon.

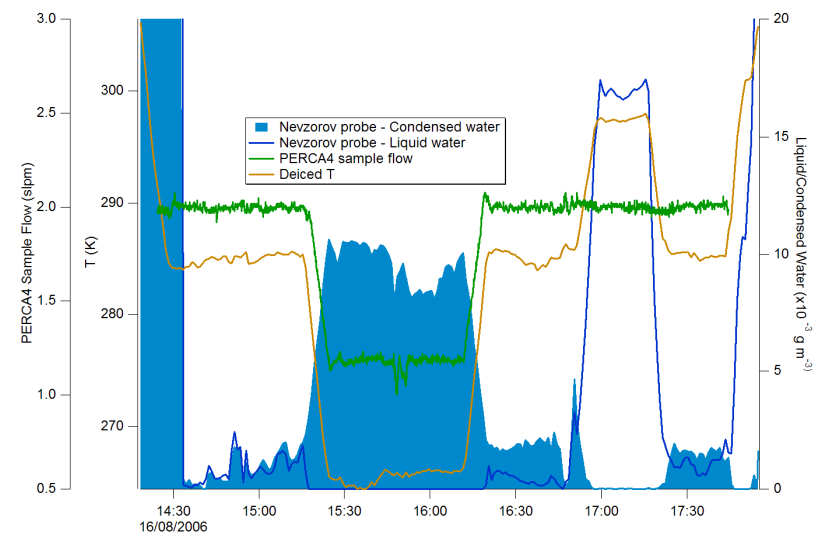

Fig. 6. Time series of PeRCA 4 sample flow, with temperature and water content during the intercomparison flight.

The simultaneous drop in sample flow with a phase change in water is seen to indicate condensation followed by freezing occurs, which then blocks the sample flow to the inlet. The combination of the ambient temperature dropping below freezing and elevated ice content coincident to a drop in sample flow is common in all AMMA flights where the PeRCA 4 instrument was operational on board the BAe-146. There has as yet been no experimental verification to quantify the level of humidity within the inlet in flight.

$\left[\mathrm{RO}_{2} *\right.$-PeRCA 4] are only available for the first pressure level measured $(697 \mathrm{hPa})$ owing to a loss of sample airflow at the higher altitude. As can be seen in Fig. 5, within this level $\left[\mathrm{RO}_{2}^{*}\right]$ vary between 15 and $35 \mathrm{pptv}$ and $\left[\mathrm{HO}_{2}\right]$ between 18 and $20 \mathrm{pptv}$. If the humidity correction is not applied, $\left[\mathrm{RO}_{2} *\right.$-PeRCA 4] and [RO $\mathrm{RO}_{2}^{*}$-DUALER] agree within their respective errors, otherwise $\left[\mathrm{RO}_{2}^{*}\right.$-PERCA 4$]$ is significantly greater. At the second pressure level $(485 \mathrm{hPa})$, the variability of $\left[\mathrm{RO}_{2}^{*}\right.$-DUALER] increases although the range of con- centrations remains generally between 15 and 45 pptv. There is no indication of any experimental artefact related to the 45 pptv [ $\mathrm{RO}_{2}^{*}$-DUALER] measured at the beginning of the layer. This apparent outlier mixing ratio agrees temporally with short term peak variations of other trace gases measured (acetone, $\mathrm{CO}, \mathrm{O}_{3}$ ).

For this leg $\left[\mathrm{HO}_{2}\right]$ varies within and 6 and $18 \mathrm{pptv}$ and the temporal variation shows two abrupt steps at 15:35 and 15:42 $\mathrm{h}$. Both of these steps follow periods where the laser wavelength is rescanned to the maximum of the $\mathrm{OH}$ rotational line. This rescanning process takes ca. 2 min and no ambient data are collect during this procedure. Laser diagnostic measurements of power and wavelength stability during the three $\mathrm{HO}_{2}$ measurement periods in this leg show there is no evidence to suggest that the instrument sensitivity has undergone a change and it is concluded that the two steps in the $\mathrm{HO}_{2}$ concentration are real variations. It can be demonstrated that the observed $\left[\mathrm{HO}_{2}\right]$ is directly and linearly proportional to the excitation laser power which is monitored at $1 \mathrm{~Hz}$ during ambient measurements and used to normalize the observed signal. This normalization procedure has been applied to the data in question. The relationship between the observed $\left[\mathrm{HO}_{2}\right]$ and excitation wavelength is non-linear and is an integration of the laser wavelength and line width and the $\mathrm{OH}$ rotational line width. A confirmation that the laser wavelength was centered on the $\mathrm{OH}$ rotational line throughout this period before and after the rescanning process is obtained by monitoring the signal produced in the $\mathrm{OH}$ reference cell in which a high and very stable $[\mathrm{OH}]$ (produced by the thermolysis of water vapour) is probed by a measured laser power. The signal obtained from the reference cell during the period where the steps in ambient $\left[\mathrm{HO}_{2}\right]$ were observed was stable. The additional factor which affects the observed $\left[\mathrm{HO}_{2}\right]$ is the flow rate of $\mathrm{NO}$ into the detection cell, and again the relationship is non-linear, but the flow of NO is controlled and measured by used of a thermal mass flow controller and 


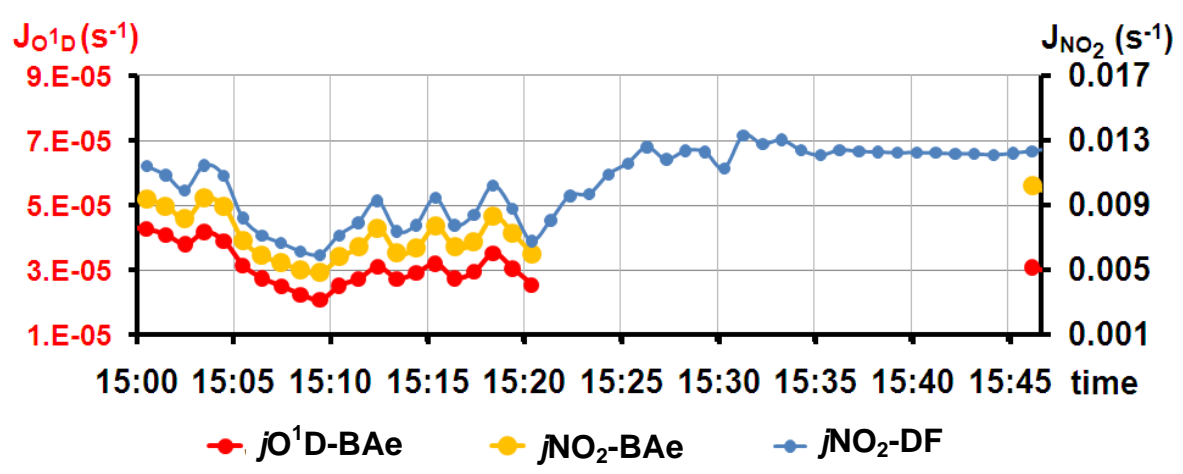

Fig. 7. Temporal variability of the photolysis rates measured during the AMMA intercomparison exercise. DF stands for D-Falcon and BAe for BAe-146.

during this ambient measurement period the flow was at the set point value of $10.0 \mathrm{sccm}$. Therefore there is no indication of any systematic variation in instrument sensitivity to $\mathrm{HO}_{2}$ in this period.

Interestingly, the variations of $\left[\mathrm{RO}_{2}^{*}\right.$-DUALER] and $\left[\mathrm{HO}_{2}\right]$ do not agree temporally, in particular for the flight period between 15:35-15:45 h. As the $\left[\mathrm{HO}_{2}\right]$ remains very even, the $\left[\mathrm{RO}_{2}^{*}\right.$-DUALER] seems to mirror a change in the radical partitioning of the air mass sampled in favour of organic peroxy radicals.

In principle, the atmospheric radical variability is driven by radiation and/or other trace gas variability. Therefore, the radical temporal evolution observed during the flight was compared with the variability of the photolysis frequencies and radical precursors measured simultaneously.

\subsection{Photolysis rates}

Measurements of $j\left(\mathrm{NO}_{2}\right)$ and $j\left(\mathrm{O}^{1} \mathrm{D}\right)$ are presented in Fig. 7. There is no BAe-146 data for the second intercomparison level as the field of view of the downward facing radiometers were obscured owing to the deployment of a protective shutter.

$j\left(\mathrm{O}^{1} \mathrm{D}\right)$ was not measured on board the D-Falcon. At $697 \mathrm{hPa}$, a systematical difference between $j\left(\mathrm{NO}_{2}\right)$ radiometers on both aircrafts was identified (see Fig. 7). While the downward facing $j\left(\mathrm{NO}_{2}\right)$ radiometers show very good agreement (within 6\%), the D-Falcon upward $j\left(\mathrm{NO}_{2}\right)$ radiometer is about $25-35 \%$ systematically higher than the BAe-146 upward facing sensor at both pressure levels. According to Volz-Thomas et al. (1996), temperature variations between 25 and $-40{ }^{\circ} \mathrm{C}$ can only account for $2-3 \%$ changing in the instrument sensitivity. The calibrations of the upper and lower $j\left(\mathrm{NO}_{2}\right)$ radiometers in the BAe- 146 before and after AMMA are consistent with one another having both been referenced to the TUV radiation model. Calibrations of the D-Falcon sensors carried out before and after the AMMA campaign show little variance $(6 \%)$. The downward facing radiometers are mainly exposed to indirect diffuse radiation while the upward facing radiometers get both, direct and diffuse radiation. As a consequence, upward looking radiometers have an additional uncertainty due to the azimuth and zenith dependence of the radiometer sensitivity. Previous investigation has shown that the total combined accuracy of the DFalcon upward looking radiometer is $14 \%$ and of the downward looking radiometer is $3 \%$. If both radiometers are subject to similar errors, it is reasonable that the upward facing $j\left(\mathrm{NO}_{2}\right)$ measurements, with lower accuracy, show a larger difference within the combined total errors, than the downward facing radiometers. Differences in the surface reflectivity around the sensors in each aircraft may also affect the result.

The temporal variations observed in $j\left(\mathrm{NO}_{2}\right)$ and $j\left(\mathrm{O}^{1} \mathrm{D}\right)$ agree qualitatively with the decrease in radical production measured between 15:05 and 15:10 h at $697 \mathrm{hPa}$ but do not correlate at all with the radical variability observed at $485 \mathrm{hPa}$.

\subsection{Radical related trace gases}

Concerning other related trace gases, $\mathrm{NO}$ and $\mathrm{NO}_{\mathrm{x}}$ remain around the detection limit. Both $\mathrm{NO}_{\mathrm{y}}$ (D-Falcon) and PAN (BAe-146) are significant higher at $485 \mathrm{hPa}$ (Stewart et al., 2008) as are $\mathrm{CO}_{2}$ (not shown, $\Delta \mathrm{CO}_{2} \sim 1 \mathrm{ppm}$ ), $\mathrm{CO}$ and $\mathrm{O}_{3}$. The $\left[\mathrm{RO}_{2}^{*}\right.$-DUALER] variations closely follow the changes in [CO] between 15:30 and 15:50 h (Fig. 8), the minimum in the $[\mathrm{CO}] /\left[\mathrm{O}_{3}\right]$ ratio at $15: 45$ indicating horizontal advection of an air mass enriched in $\mathrm{CO}$ rather than vertical convection, as $[\mathrm{CO}]$ remains lower in the previous higher altitude run at $697 \mathrm{hPa}$.

Acetone measured by PTR-MS shows minor short term variations in both pressure levels, and similarly to the HCHO measured on board the D-Falcon decreases slightly at $495 \mathrm{hPa}$ on average from $1 \mathrm{ppbv}$ to $0.8 \mathrm{ppbv}$. The corresponding WAS results indicate more marked peak concentrations at 15:30 in acetone and also in acetaldehyde which likely result from the integration related to the lower time resolution of the WAS samples. 

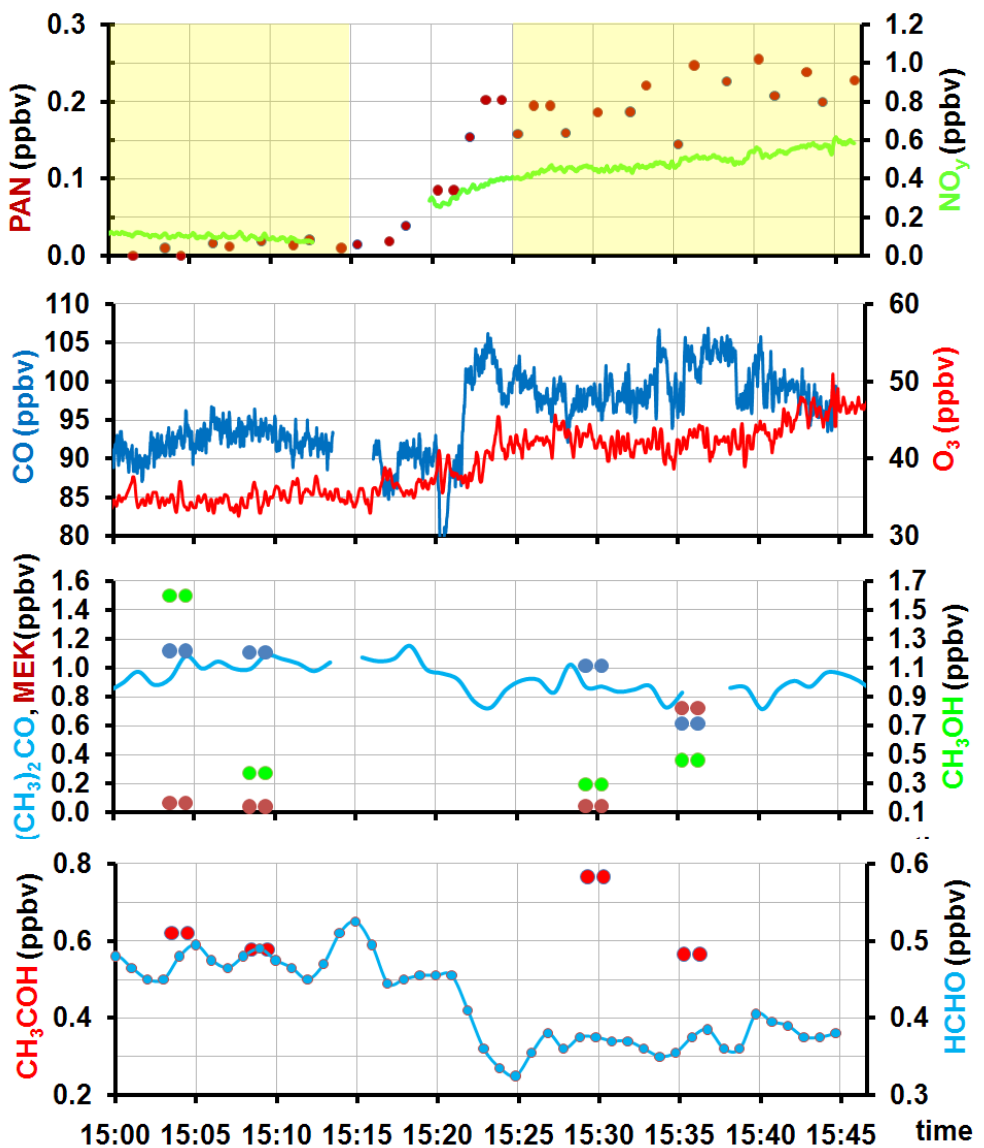

Fig. 8. Variation of related trace gases during the AMMA radical intercomparison exercise: $\mathrm{CO}, \mathrm{O}_{3}, \mathrm{NO}_{\mathrm{y}}$, and $\mathrm{HCHO}$ as measured on board the D-Falcon, $\left(\mathrm{CH}_{3}\right)_{2} \mathrm{CO}, \mathrm{CH}_{3} \mathrm{COH}$, MEK, PAN and $\mathrm{CH}_{3} \mathrm{OH}$ as measured on board the BAe-146. The $\left(\mathrm{CH}_{3}\right)_{2} \mathrm{CO}$ measured by PTR-MS (blue line) agree reasonably with the WAS samples (blue dots). The periods of the intercomparison are highlighted in the top figure in yelow.

Isoprene and its oxidation products MVK and MACR (not shown) remain low and relatively constant, not indicating any recent influence of biogenic VOC.

Owing to the strong altitude dependence on the sampling and zeros reported by Murphy et al. (2010) during the AMMA measurement campaign, no PTR $\mathrm{CH}_{3} \mathrm{OH}$ data are available for the intercomparison period. The GC analysis of the WAS samples at lower time resolution shows a significant $\mathrm{CH}_{3} \mathrm{OH}$ maximum (1.6 ppbv) at the beginning of the first pressure level (around 15:00 h) and an increase from 0.3 to $0.5 \mathrm{ppbv}$ between $15: 30$ and $15: 35 \mathrm{~h}$ at $485 \mathrm{hPa}$. Similarly, MEK increases from 0.05 to $0.7 \mathrm{ppbv}$ at $15: 35 \mathrm{~h}$. MEK is an indicator of industrial and gasoline engine emissions, and its major sink is the reaction with $\mathrm{OH}$ producing acetaldehyde. Apart from biogenic emissions, $\mathrm{CH}_{3} \mathrm{OH}$ is produced by reaction of the methylperoxy radical with itself and other organic peroxy radicals (Madronich and Calvert, 1990; Tyndall et al., 2001):

$\mathrm{CH}_{3} \mathrm{O}_{2}+\mathrm{CH}_{3} \mathrm{O}_{2} \rightarrow \mathrm{CH}_{3} \mathrm{O}+\mathrm{CH}_{3} \mathrm{O}+\mathrm{O}_{2}$

$\mathrm{CH}_{3} \mathrm{O}_{2}+\mathrm{CH}_{3} \mathrm{O}_{2} \rightarrow \mathrm{CH}_{3} \mathrm{OH}+\mathrm{HCHO}+\mathrm{O}_{2}$
$\mathrm{CH}_{3} \mathrm{O}_{2}+\mathrm{RO}_{2} \rightarrow \mathrm{CH}_{3} \mathrm{O}+\mathrm{RO}+\mathrm{O}_{2}$

(R2a)

$\mathrm{CH}_{3} \mathrm{O}_{2}+\mathrm{RO}_{2} \rightarrow \mathrm{CH}_{3} \mathrm{OH}+\mathrm{R}^{\prime} \mathrm{CHO}+\mathrm{O}_{2}$

The HCHO measured on board the D-Falcon increases concurrent to $\mathrm{CH}_{3} \mathrm{OH}$ from 350 to $385 \mathrm{pptv}$. This can be considered as an upper limit of the $\mathrm{CH}_{3} \mathrm{OH}$ which can be attributed to Reaction (R1b). Other minor sources of methanol are biomass burning and biofuels and fossil fuel combustion and industrial activities, as in the case of MEK. Acetonitrile and benzene do not provide any indication of recent biomass burning influence in the air mass.

Summarising, the variability of the trace gases measured at the second pressure level of the intercomparison exercise indicate changes in the composition of the air mass sampled which can reasonably be correlated to the variability of the local peroxy radicals measured. 

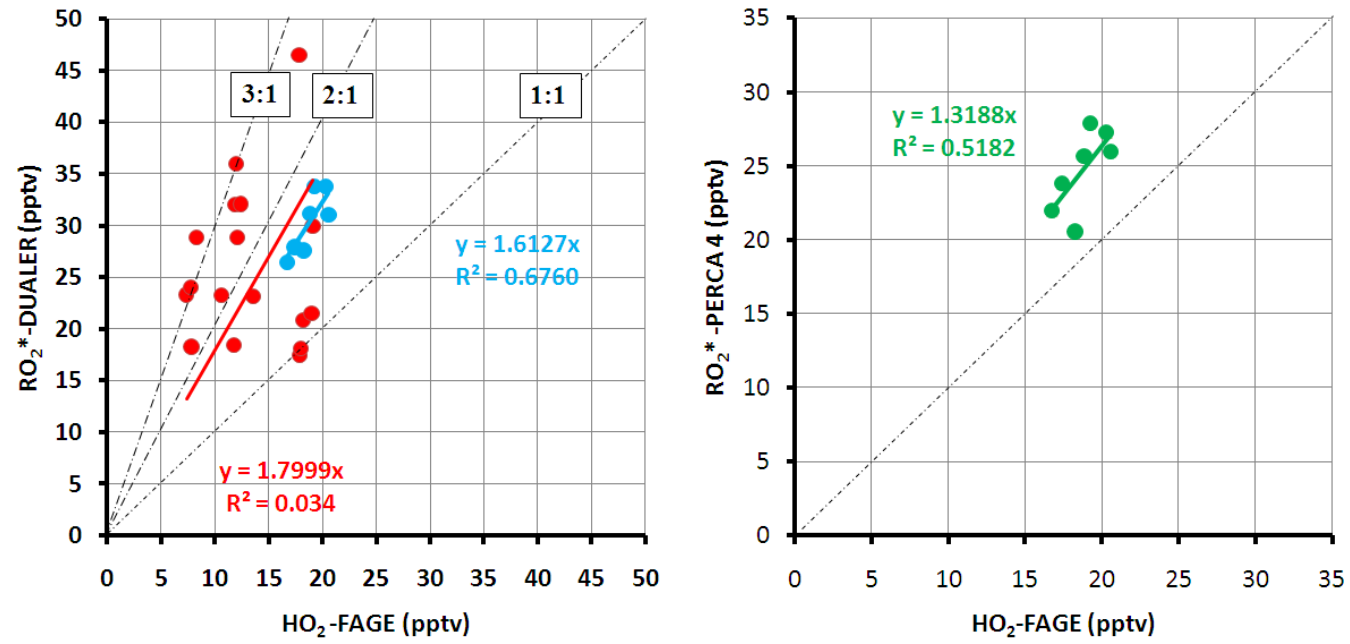

Fig. 9. $\left[\mathrm{RO}_{2}^{*}\right] /\left[\mathrm{HO}_{2}\right]$ ratio measured during the AMMA intercomparsion exercise. In blue and green are the data corresponding to the first pressure level measured $(697 \mathrm{hPa})$.

\subsection{Radical partitioning}

Figure 9 shows the ratio $\left(\left[\mathrm{RO}_{2}^{*}\right.\right.$-DUALER $\left.] /\left[\mathrm{HO}_{2}\right]\right)$ for both measured levels. At $697 \mathrm{hPa}$, both the variability of the measured mixing ratios and the number of $\mathrm{HO}_{2}$ measurements available is smaller and the ratio seems to remain quite stable around 2.5. This ratio is more scattered at $485 \mathrm{hPa}$, remaining between 1 and 3 as result of the variability of $\left[\mathrm{RO}_{2}^{*}\right]$ discussed above. There are only a few $\left[\mathrm{RO}_{2}^{*}\right] /\left[\mathrm{HO}_{2}\right]$ values reported for the upper troposphere (1.86: Cantrell et al, 2003a; 1.25: Cantrell et al., 2003c). It is important to emphasise that $\left[\mathrm{RO}_{2}^{*}\right] /\left[\mathrm{HO}_{2}\right]$ is not expected to be constant but to be directly related to the NO and $\mathrm{VOC}$ content and history of the air mass sampled.

A similar comparison between $\left[\mathrm{HO}_{2}\right]$ and $\left[\mathrm{RO}_{2}^{*}\right]$ measured by LIF and Chemical Ionisation Mass Spectrometry (CIMS) respectively was undertaken within the TRACE-P measurement campaign (Eisele et al., 2003; Cantrell et al., 2003a, b). The $\left[\mathrm{RO}_{2}^{*}\right]$ versus $\left[\mathrm{HO}_{2}\right]$ average data, are quite scattered as expected since the $\left[\mathrm{RO}_{2}\right] /\left[\mathrm{HO}_{2}\right]$ ratio is not necessarily constant during the three sets of intercomparison flights, but can reasonably be fitted by a slope of 2.46 .

The CL of the DUALER measured in the laboratory is an effective CL (eCL) coming from the chain reaction of the radicals not being lost in the pre-reactor nozzle. As the peroxy radicals are reacting rapidly with the walls, the losses at this nozzle before the addition of $\mathrm{CO}$ and $\mathrm{NO}$ are expected to be important. According to the laboratory characterisation of the response of the DUALER for different peroxy radicals (Kartal et al., 2010), higher eCL is to be expected for $\mathrm{CH}_{3} \mathrm{O}_{2}$ than for $\mathrm{HO}_{2}$ as a consequence of lower wall losses of $\mathrm{CH}_{3} \mathrm{O}_{2}$ in the pre-reactor nozzle. Using a common eCL for the determination of $\left[\mathrm{RO}_{2}^{*}\right]$ in ambient samples as during AMMA can cause an overestimation depending on the
$\left[\mathrm{HO}_{2}\right] /\left[\mathrm{CH}_{3} \mathrm{O}_{2}\right]$ ratio. The $\left[\mathrm{RO}_{2}\right] /\left[\mathrm{HO}_{2}\right]$ ratios vary mostly between 1:1 and 2:1 during the intercomparison exercise and $\mathrm{CH}_{3} \mathrm{O}_{2}$ is expected to constitute $88 \%$ of the total organic peroxy radicals (see Sect. 4.4). Under these conditions the experimental $\left[\mathrm{RO}_{2}^{*}\right.$-DUALER] reported in this work might be 8 to $16 \%$ overestimated.

Radical partitioning over the whole AMMA campaign derived from the simultaneous measurement of $\left[\mathrm{RO}_{2}^{*}\right]$ and $\left[\mathrm{HO}_{2}\right]$ on board the BAe-146 is discussed more in detail in Brookes (2009).

\subsection{Modelling of radical concentrations}

Comparisons between modelled $\left[\mathrm{HO}_{2}\right]$ and $\left[\mathrm{RO}_{2}^{*}\right]$ with observations are shown in Figs. 10-12. As mentioned above, $\mathrm{HO}_{2}$ was only partially measured at $697 \mathrm{hPa}$ and $\mathrm{RO}_{2}^{*}-$ PeRCA 4 is completely unavailable for the second intercomparison period. This reduces drastically the statistics and representativeness of the results obtained within the intercomparison exercise.

At a first glance the model results in Fig. 10 seem to generally overestimate $\left[\mathrm{HO}_{2}\right]$ during the intercomparison exercise, which results in some overprediction of total modelled $\left[\mathrm{RO}_{2}^{*}\right]$. It is possible that flying adjacent to the D-Falcon may have had some effect on the flow conditions within the FAGE inlet, resulting in greater loss of $\mathrm{HO}_{2}$ in the inlet and reduced $\mathrm{HO}_{2}$ detection compared to calibration conditions, although such effects have not been reported in previous aircraft $\mathrm{HO}_{\mathrm{x}}$ intercomparison exercises (Eisele et al., 2003). This might partly explain the stepwise temporal evolution of $\left[\mathrm{HO}_{2}\right] \mathrm{ob}-$ served at $485 \mathrm{hPa}$.

It is important noting that the use of the model in particular for the AMMA intercomparison period is subject to important restrictions derived from following issues: 


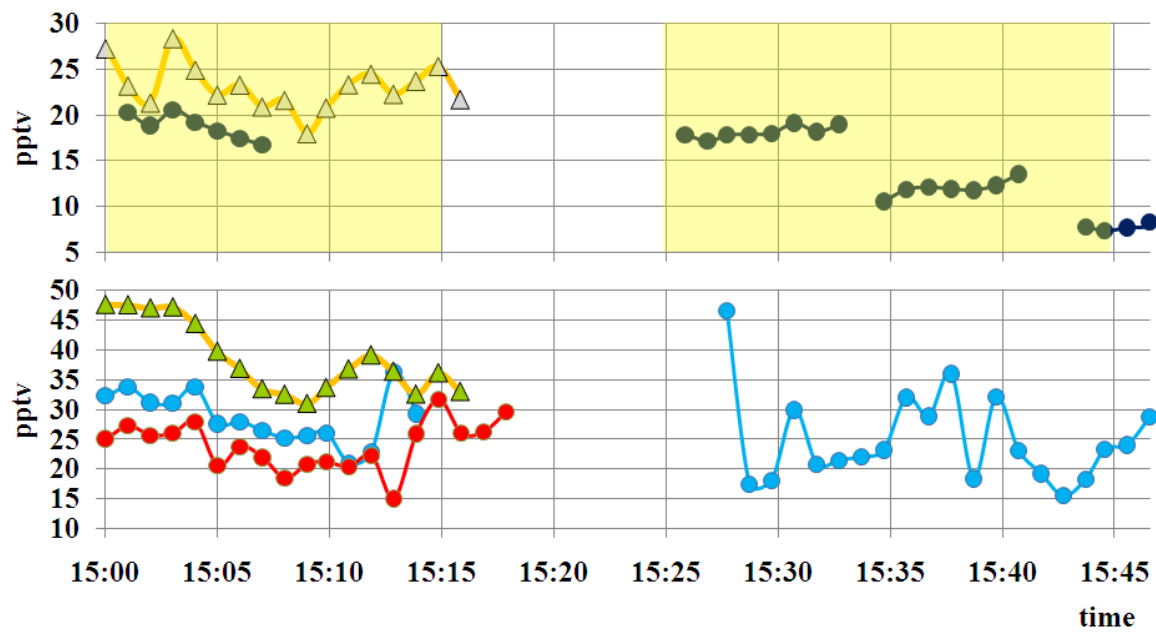

Fig. 10. Comparison of model and observations ([HO $\left.\mathrm{HO}_{2}-\mathrm{FAGE}\right]$ in dark blue, $\left[\mathrm{RO}_{2}^{*}\right.$-DUALER] in blue and $\left[\mathrm{RO}_{2}^{*}\right.$-PeRCA 4$]$ in red) for the $697 \mathrm{hPa}$ pressure level during the intercomparison exercise. Model results (triangles) are constrained to $j\left(\mathrm{NO}_{2}\right)$ and $j\left(\mathrm{O}^{1} \mathrm{D}\right)$ measured on board the BAe-146. The periods of the intercomparison are highlighted in the top figure in yelow.

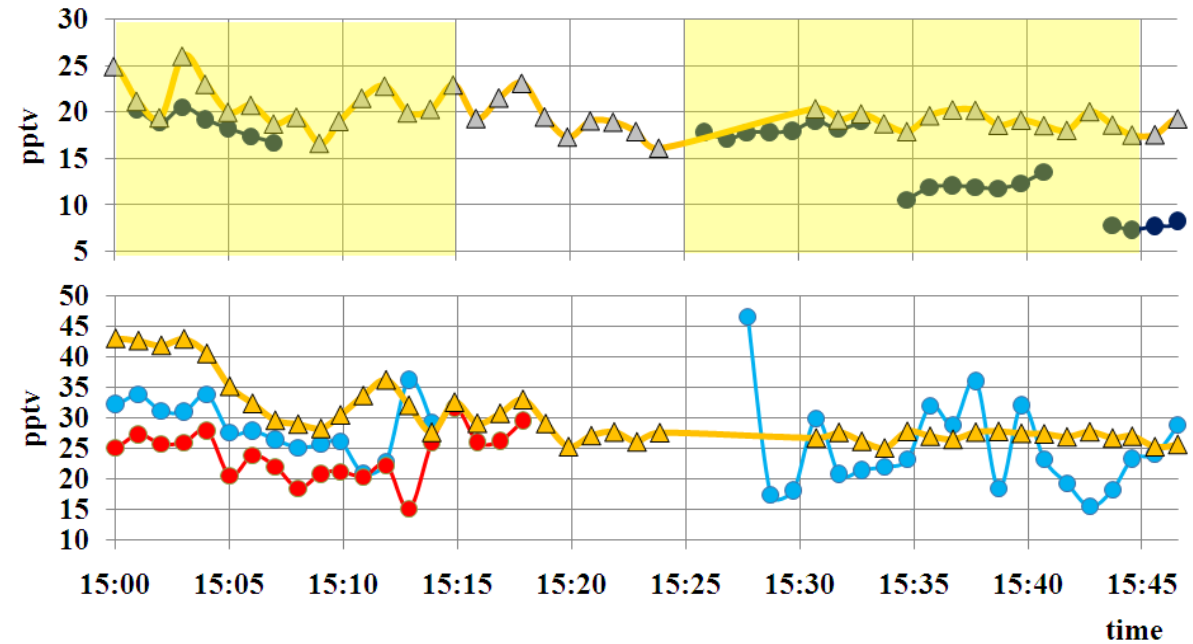

Fig. 11. Comparison of model and observations ( $\left[\mathrm{HO}_{2}\right]$ in dark blue, $\left[\mathrm{RO}_{2}^{*}-\mathrm{DUALER}\right]$ in blue and $\left[\mathrm{RO}_{2}^{*}-\mathrm{PeRCA} 4\right]$ in red) for the $697 \mathrm{hPa}$ pressure level during the intercomparison exercise. Model results (triangles) are constrained to $j\left(\mathrm{NO}_{2}\right)$ measured on board the $\mathrm{D}$-Falcon scaled to the $j\left(\mathrm{NO}_{2}\right)$-BAe values measured at $697 \mathrm{hPa}$. The periods of the intercomparison are highlighted in the top figure in yelow.

(a) Photolysis rates:

As described in Sect. 3, the DSMACC model requires observations of $j\left(\mathrm{NO}_{2}\right)$ and $j\left(\mathrm{O}^{1} \mathrm{D}\right)$, which were not available for the second altitude level. The existing discrepancies between $j\left(\mathrm{NO}_{2}\right)$ measured on board the BAE-146 and DFalcon prevent the direct use of the $j\left(\mathrm{NO}_{2}\right)$-D-Falcon data for the $485 \mathrm{hPa}$ pressure level without introducing unknown uncertainties. Model runs using $j\left(\mathrm{NO}_{2}\right)$-D-Falcon show higher radical concentrations than model runs constrained to photolysis rates measured on the BAe-146 as expected since the $j\left(\mathrm{NO}_{2}\right)$-D-Falcon measurement is systematically
$25 \%$ higher than the $j\left(\mathrm{NO}_{2}\right)$-BAe-146 measurement (see Fig. 7). Scaling of the $j\left(\mathrm{NO}_{2}\right)$-D-Falcon to the values observed on the BAe-146 gives similar results to model results constrained to the BAe-146 photolysis results, and provides some additional data points during the second intercomparison period (Fig. 11). The agreement between $\left[\mathrm{HO}_{2}\right]$ modelled and measured improves and the modelled $\left[\mathrm{RO}_{2}^{*}\right]$ for the second period show good agreement on the average with the observed [ $\mathrm{RO}_{2}^{*}$-DUALER] though the short term variability of the observations is not completely picked up (Fig. 12). 


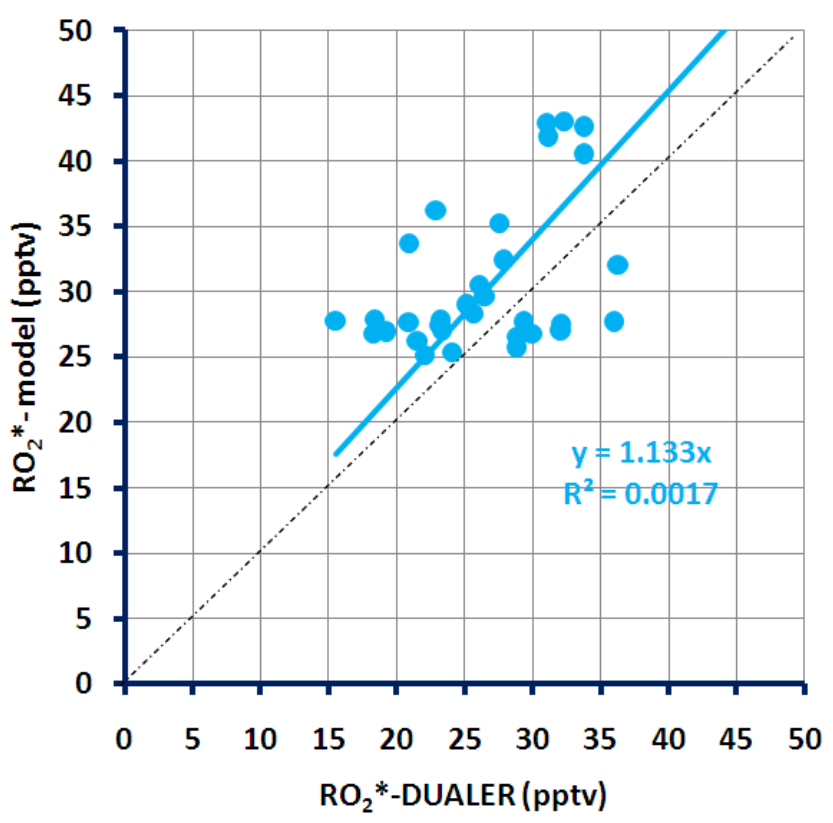

Fig. 12. $\left[\mathrm{HO}_{2}+\mathrm{RO}_{2}\right]$ model versus $\left[\mathrm{RO}_{2}^{*}\right]$ observations on board the D-Falcon for both altitudes during the AMMA intercomparison exercise. The model is constrained to $j\left(\mathrm{NO}_{2}\right)$ measured on board the D-Falcon scaled to the $j\left(\mathrm{NO}_{2}\right)$-BAe values measured at $697 \mathrm{hPa}$.

Concerning $j\left(\mathrm{O}^{1} \mathrm{D}\right)$, the BAe-146 measurements may have been subject to a systematic bias derived from the non-linearity of $j\left(\mathrm{O}^{1} \mathrm{D}\right)$ calibration factors for total $\mathrm{O}_{3}$ column, temperature and solar zenith angle, as described in Stone et al. (2010) and Brookes (2009). This results in a potential requirement for reduction in $j\left(\mathrm{O}^{1} \mathrm{D}\right)$ by a factor of 0.7. The bias appears more significant at altitudes above $4 \mathrm{~km}$ where the impact of cloud and aerosol is much reduced. A similar correction to the $j\left(\mathrm{O}^{1} \mathrm{D}\right)$ in the model did result in a lowering of the modelled $\mathrm{HO}_{2}$, and although the reduction in $j\left(\mathrm{O}^{1} \mathrm{D}\right)$ rectifies much of the overestimation for $\mathrm{HO}_{2}$ in the model, it was not sufficient to explain the model discrepancy during the intercomparison period.

(b) Input of trace gas observations:

There are a limited number of VOC observations at high temporal resolution during the intercomparison period. As the input for the model is updated every $60 \mathrm{~s}$, the use of WAS samples with $15 \mathrm{~min}$ resolution can introduce unrealistic stepwise significant variations in the mixing ratio of trace gases. In addition, as reported on Reeves et al. (2010) the HCHO measured on board the BAe-146 showed unrealistic oscillations during the intercomparison exercise. Figure 13 compares the HCHO output of the model with the HCHO measured on board the D-Falcon. Furthermore, as the $\mathrm{NO}_{\mathrm{x}}$ mixing ratios remained below the detection limit of the instruments deployed, the comparison of the model with a reliable experimental reference as described in Sect. 3 is not possible.

The importance of some of these issues in the application of box models to observationally based predictions of $\mathrm{HO}_{\mathrm{x}}$ radicals has been recently evaluated by Olson et al. (2004, 2006). The present work intends to focus on the analysis of the uncertainties of experimental data rather than on the comparison with model results. Given the limitations described above and the inherent challenges of the airborne radical measurement and modelling, the overestimate of $\mathrm{HO}_{2}$ during the intercomparison period does not appear to be an indication of an inability in the model to replicate observations of $\mathrm{HO}_{2}$. In fact there is no significant overestimation of measured $\left[\mathrm{HO}_{2}\right]$ for the modelling of the AMMA campaign as a whole, as discussed in Stone et al. (2010) and summarised in Fig. 14. The major uncertainty in the model derives from the uncertainty in the measured photolysis rates. Model sensitivity to input parameters, is discussed in detail in Stone et al. (2010), and show that any overestimation of radical species in the model may be explained by the uncertainty in measured photolysis rates. The model does, however, replicate the variability in observations, as shown in Figure 14 and evidenced by the $r^{2}$ correlation coefficient of 0.75 between the modelled and measured $\mathrm{HO}_{2}$ concentrations.

Rates of production/destruction analyses (ROPAs/RODAs) for the model run using photolysis rates measured on the BAe-146 indicates that the dominant reactions responsible for $\mathrm{HO}_{2}$ production during the intercomparison periods were $\mathrm{OH}+\mathrm{CO}(39 \%), \mathrm{CH}_{3} \mathrm{O}+\mathrm{O}_{2}$ (15\%), $\mathrm{HCHO}+\mathrm{OH}(10 \%)$ and $\mathrm{HCHO}$ photolysis (9\%). While individual contributions to $\mathrm{HO}_{2}$ production from $\mathrm{RO}+\mathrm{O}_{2}$ reactions are relatively small, they do contribute significantly to the remainder of the total.

Dominant loss processes for $\mathrm{HO}_{2}$ were $\mathrm{HO}_{2}+\mathrm{NO}$, comprising $35 \%$ of the total loss, $\mathrm{HO}_{2}+\mathrm{HO}_{2}(28 \%)$, $\mathrm{HO}_{2}+\mathrm{CH}_{3} \mathrm{O}_{2}(11 \%)$ and $\mathrm{O}_{3}+\mathrm{HO}_{2}(8 \%)$. Cycling of $\mathrm{HO}_{2}$ between the $\mathrm{HO}_{2}$ and $\mathrm{HO}_{2} \mathrm{NO}_{2}$ was also a significant process during the intercomparison periods, and reactions of $\mathrm{HO}_{2}$ with $\mathrm{RO}_{2}$ species also contributes significantly to the total $\mathrm{HO}_{2}$ loss.

The dominant peroxy species in terms of $\mathrm{HO}_{2}$ loss were also the most abundant $\mathrm{RO}_{2}$ species in the model, with $\mathrm{CH}_{3} \mathrm{O}_{2}$ constituting $88 \%$ of the total organic peroxy radical concentration. A more detailed $\mathrm{RO}_{2}$ speciation from the model is given in Table 2 .

\section{Summary and conclusions}

The measurement of peroxy radicals requires the use of very sensitive and well calibrated measurement techniques. Owing to the particular complexity of airborne measurements, any laboratory characterisation must however be accompanied by in flight intercomparisons and calibrations of the 


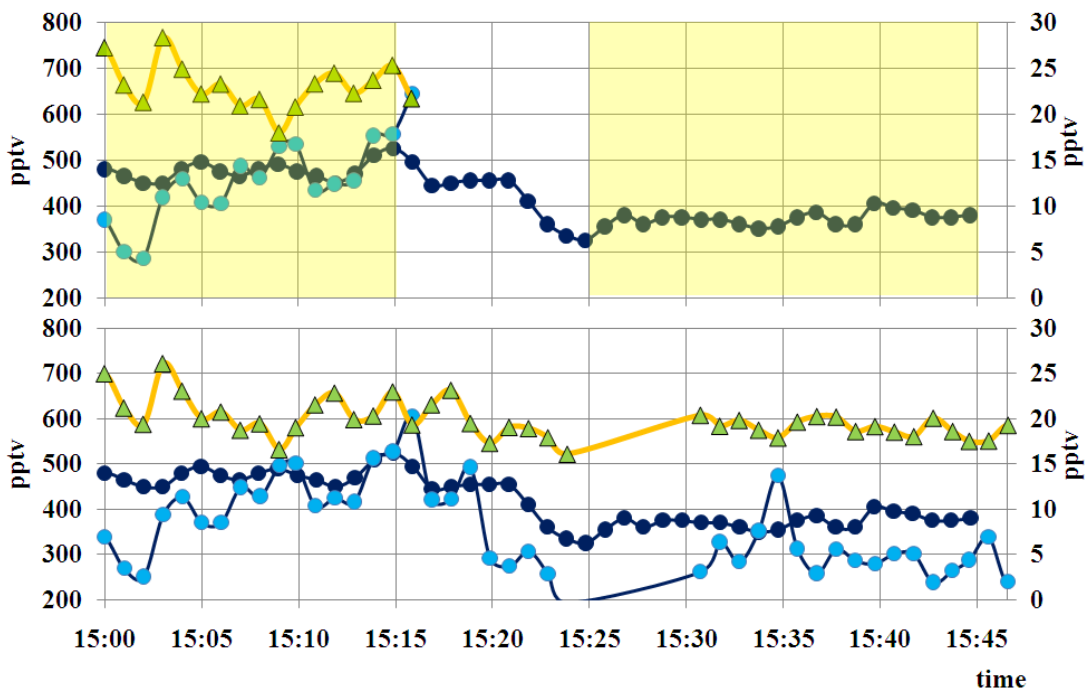

Fig. 13. $[\mathrm{HCHO}]$ measured on board the D-Falcon (dark blue circles) and modeled (blue) for the intercomparison exercise. The model data are constrained to $j\left(\mathrm{NO}_{2}\right)$ measured on board the BAe-146 (top) or to $j\left(\mathrm{NO}_{2}\right)$ measured on board the D-Falcon scaled to the $j(\mathrm{NO} 2)$-BAe values measured at $697 \mathrm{hPa}$ (botom) as in Figs. 10 and 11. The corresponding [ $\left.\mathrm{HO}_{2}\right]$ model data in ppt are also included for comparison (right $y$-axis). The periods of the intercomparison are highlighted in the top figure in yellow.

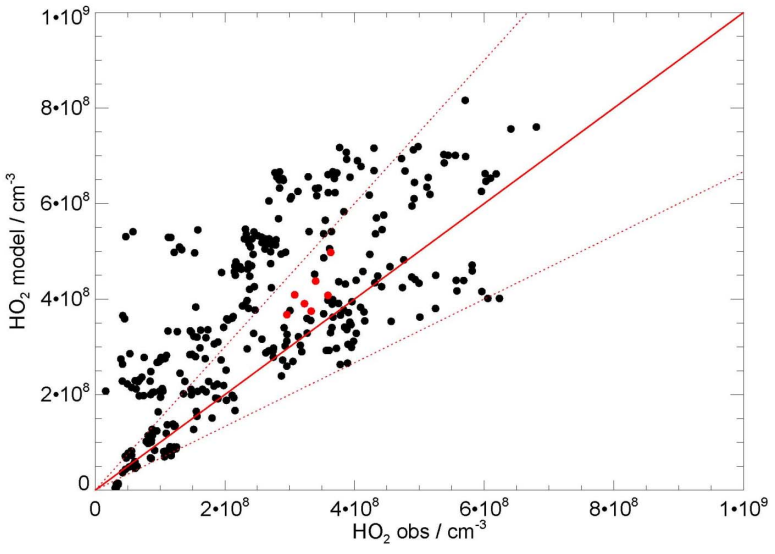

Fig. 14. Comparison between $\mathrm{HO}_{2}$ modeled and observed concentrations using measurements made on board the BAe-146. In red are the data corresponding with the intercomparison period.

instrumentation in order to identify malfunctions under field conditions and to prevent biases in the analysis of results.

In that context, the radical intercomparison exercise within AMMA intends for the first time to compare the performance of a LIF-FAGE, measuring $\left[\mathrm{HO}_{2}\right]$, and two similar PeRCA instruments, measuring the total sum of peroxy radicals $\left[\mathrm{RO}_{2}^{*}\right]$, deployed in two different aircrafts and sampling at two pressure levels over the same geographical area.

Some instrumental failures limited the number of data available for comparison. Nevertheless the results obtained provide very valuable information for the analysis of the AMMA campaign as a whole: (a) $\left[\mathrm{RO}_{2}^{*}\right.$-PeRCA 4$]$ and $\left[\mathrm{RO}_{2}^{*}\right.$-DUALER $]$ agree within the instrumental errors when the correction for the expected humidity interference to the chain chemistry in the PeRCA 4 instrument is not applied, while the $\left[\mathrm{RO}_{2}^{*}\right.$ PeRCA 4] corrected data set remains unrealistically higher. The modelled reduction in the PeRCA 4 chain length owing to the pressure and temperature dependencies of the chain chemistry reaction rate coefficients does explain a significant proportion of the systematic offset between the PeRCA 4 and DUALER measurements. The demonstrated lack of a trend in the model to measurement ratio with relative humidity further supports the conclusion that under the conditions of the aircraft measurements the chain length is unperturbed by the ambient levels of humidity. The measurements otherwise show the same temporal variation and agree in magnitude within the instrumental uncertainties. This support the conclusion that it is inappropriate to use the humidity corrected data from the PeRCA 4 instrument for the rest of the AMMA campaign.

(b) The response of the $j\left(\mathrm{NO}_{2}\right)$ radiometer on board the D-Falcon remains systematically higher than the equivalent radiometer on the BAe-146. This is the result of the $25-35 \%$ difference observed in the upward facing sensors at both pressure levels. This difference remains within the combined total errors of both radiometers which is mainly related to the azimuth and zenith dependence of the sensitivity of upward facing radiometers. This emphasises the importance of specific calibrations and verification of $2 \pi$ sr radiometers to preventspuriously simulation of radical mixing ratios, 
Table 2. Organic $\mathrm{RO}_{2}$ speciation from DSMACC during the intercomparison period. Species names are from the MCM. Note that $\mathrm{ISOPAO}_{2}, \mathrm{ISOPBO}_{2}, \mathrm{ISOPDO}_{2}, \mathrm{C} 57 \mathrm{O}_{2}, \mathrm{C} 58 \mathrm{O}_{2}, \mathrm{C} 59 \mathrm{O}_{2}$, $\mathrm{HMVKAO}_{2}, \mathrm{HMVKBO}_{2}$ and $\mathrm{MACRO}_{2}$ are all derived from isoprene and its oxidation products.

\begin{tabular}{lr}
\hline $\mathrm{RO}_{2}$ & $\begin{array}{r}\text { \% to total organic } \\
\mathrm{RO}_{2} \text { concentration }\end{array}$ \\
\hline $\mathrm{CH}_{3} \mathrm{O}_{2}$ & 87.96 \\
$\mathrm{ISOPBO}_{2}$ & 2.50 \\
$\mathrm{CH}_{3} \mathrm{CO}_{3}$ & 2.01 \\
$\mathrm{CH}_{3} \mathrm{COCH}_{2} \mathrm{O}_{2}$ & 1.08 \\
$\mathrm{C}_{2} \mathrm{H}_{5} \mathrm{O}_{2}$ & 0.89 \\
$\mathrm{HOCH}_{2} \mathrm{CO}_{3}$ & 0.75 \\
$\mathrm{C}_{59 O}$ & 0.65 \\
$\mathrm{HMVKBO}_{2}$ & 0.62 \\
$\mathrm{MACRO}_{2}$ & 0.58 \\
$\mathrm{ISOPDO}_{2}$ & 0.41 \\
$\mathrm{C} 58 \mathrm{O}_{2}$ & 0.36 \\
$\mathrm{C}_{27 O}$ & 0.29 \\
$\mathrm{ISOPAO}_{2}$ & 0.26 \\
$\mathrm{HMVKAO}_{2}$ & 0.26 \\
Remaining & 1.38 \\
\hline
\end{tabular}

as confirmed by the sensitivity study undertaken with the DSMACC model. These discrepancies require exercising caution when comparing model results from the two aircrafts.

Concerning the content of the air masses sampled, the radical mixing ratios vary on the average between 7 and 20 pptv for $\left[\mathrm{HO}_{2}\right]$ and 15 and $40 \mathrm{pptv}$ for $\left[\mathrm{RO}_{2}^{*}\right]$ at both pressure levels. The $\left[\mathrm{RO}_{2}^{*}\right]$ variability increases significantly at the higher pressure level $(485 \mathrm{hPa})$ indicating input of precursors of organic peroxy radicals, in reasonable agreement with other trace gas observations. The existence of a layer photochemically active at this altitude has been reported during AMMA (Andrés-Hernández et al., 2009; Reeves et al., 2010). The $\left[\mathrm{RO}_{2}^{*}\right] /\left[\mathrm{HO}_{2}\right]$ ratios vary between $1: 1$ and $3: 1$ and seem to be more stable and closer to the expected $2: 1$ for remote areas at the lower pressure level $(697 \mathrm{hPa})$. According to the laboratory characterisation of the DUALER (Kartal et al., 2010), using a common chain length for the $\left[\mathrm{RO}_{2}^{*}\right]$ determination during the intercomparison exercise can lead to an $8-16 \%$ overestimation of the reported [ $\mathrm{RO}_{2}^{*}$-DUALER].

The results of this intercomparison campaign confirm the necessity of additional effort to improve not only the inflight cross calibration of airborne measurements for peroxy radicals but also the rapid and high sensitive measurement of photolysis rates and other associated species like VOCs and NO, which play a central role in the discrimination between unexpected experimental malfunctions and unknown atmospheric chemistry. Furthermore, the broad and accurate knowledge of instrumental limitations and potential artefacts in the field is indispensable for the correct use of airborne measurements of short lived species for the modelling of local photochemistry.

Acknowledgements. The authors would like to thank all the DLR colleagues, FAAM staff and the D-Falcon and BAe-146 crews for their support before, during and after the AMMA measurement campaign. Special thanks to Jim MacQuaid, Jim Hopkins, James Lee and Jennifer Murphy for supplying some of the data used in this work. The DLR-Falcon operation was funded in part by DLR and the BAe-146 by NERC through the AMMA-UK Consortium project. Both aircraft received funding from the European Commission.

Based on a French initiative, AMMA was built by an international scientific group and is currently funded by a large number of agencies. It has been the beneficiary of a major financial contribution from the European Community Sixth Framework Research Programme. Detail information on scientific coordination and funding is available on the AMMA International web site at https://www.amma-eu.org/.

Edited by: P. Formenti

\section{References}

Andrés-Hernández, M. D., Burkert, J., Reichert, L., Stöbener, D., Meyer-Arnek, J., Burrows, J. P., Dickerson, R. R., and Doddridge, B.: Marine boundary layer peroxy radical chemistry during the AEROSOLS99 campaign: measurements and analysis, J. Geophys. Res., 106(D18), 20833-20846, 2001.

Andrés-Hernández, M. D., Kartal, D., Reichert, L., Burrows, J. P., Meyer Arnek, J., Lichtenstern, M., Stock, P., and Schlager, H.: Peroxy radical observations over West Africa during AMMA 2006: photochemical activity in the outflow of convective systems, Atmos. Chem. Phys., 9, 3681-3695, doi:10.5194/acp-93681-2009, 2009.

Atkinson, R., Baulch, D. L., Cox, R. A., Crowley, J. N., Hampson, R. F., Hynes, R. G., Jenkin, M. E., Rossi, M. J., Troe, J., and IUPAC Subcommittee: Evaluated kinetic and photochemical data for atmospheric chemistry: Volume II gas phase reactions of organic species, Atmos. Chem. Phys., 6, 3625-4055, doi:10.5194/acp-6-3625-2006, 2006.

Bechara, J., Borbon, A., Jambert, C., Colomb, A., and Perros, P. E.: Evidence of the impact of deep convection on reactive volatile organic compounds in the upper tropical troposphere during the AMMA experiment in West Africa, Atmos. Chem. Phys. Discuss., 9, 20309-20346, doi:10.5194/acpd-9-20309-2009, 2009.

Brookes, D.: Characterisation of a PeRCA instrument and measurements of peroxy radicals during the West African Monsoon 2006, Ph.D. thesis, University of Leicester, UK, https: //lra.le.ac.uk/handle/2381/8328, 2009.

Brough, N., Reeves, C. E., Penkett, S. A., Stewart, D. J., Dewey, K., Kent, J., Barjat, H., Monks, P. S., Ziereis, H., Stock, P., Huntrieser, H., and Schlager, H.: Intercomparison of aircraft instruments on board the C-130 and Falcon 20 over southern Germany during EXPORT 2000, Atmos. Chem. Phys., 3, $2127-$ 2138, doi:10.5194/acp-3-2127-2003, 2003. 
Brune, W. H., Faloona, I. C., Tan, D., Weinheimer, A. J., et al.: Airborne in-situ $\mathrm{OH}$ and $\mathrm{HO}_{2}$ observations in the cloud-free troposphere and lower stratosphere during SUCCESS, Geophys. Res. Lett., 25(10), 1701-1704, 1998.

Burkert, J., Andrés-Hernández, M. D., Stöbener, D., Burrows, J. P., Weissenmayer, M., and Kraus, A.: Peroxy radical and related trace gas measurements in the boundary layer above the Atlantic Ocean, J. Geophys. Res., 106(6), 5457-5477, doi:10.1029/2000JD900613, 2001a.

Burkert, J., Behmann, T., Andrés Hernández, M. D., Weißenmayer, M., Perner, D., and Burrows, J. P.: Measurements of peroxy radicals in a forested area in Portugal, Chemosphere, 3(3), 33273338, 2001b.

Burkert, J. Andrés Hernández, M. D., Reichert, L., Stöbener, D., Meyer-Arnek, J., Burrows, J. P., Mühle, J., Zahn, A., Carsey, T., Dickerson, R. R., and Doddridge, B.: Trace gas and radical behaviour in the marine boundary layer during INDOEX 1999, J. Geophys. Res., 108(D8), 8000, doi:10.1029/2002JD002790, 2003.

Cantrell, C. A., Shetter, R. E., and Calvert, J. G.: Dual-Inlet chemical amplifier for atmospheric peroxy radical measurements, Anal. Chem., 68, 4194-4199, 1996.

Cantrell, C. A., Edwards, G. D., Stephens, S., Mauldin, L., et al.: Peroxy radical behaviour during the Transport and Chemical Evolution over the Pacific (TRACE-P) campaign as measured aboard the NASA P-3B aircraft, J. Geophys. Res., 108(D20), 8797, doi:10.1029/2003JD003674, 2003a.

Cantrell, C. A., Edwards, G. D., Stephens, S., Mauldin, L., Kosciuch, E., Zondlo, M., and Eisele, F.: Peroxy radical observations using chemical ionization mass spectrometry during TOPSE, J. Geophys. Res., 108(D6), 8371, doi:10.1029/2002JD002715, 2003b.

Cantrell, C. A., Mauldin, L., Zondlo, M., Eisele, F., et al.: Steady free radical budgets and ozone photochemistry during TOPSE, J. Geophys. Res., 108(D4), 8361, doi:10.1029/2002JD002198, 2003c.

Clemitshaw, K. C., Carpenter, L. J., Penkett S. A., and Jenkin, M. E.: A calibrated peroxy radical chemical amplifier for groundbased tropospheric measurements, J. Geophys. Res., 102(D21), 25-405, 1997.

ommane, R., Floquet, C. F. A., Ingham, T., Stone, D., Evans, M. J., and Heard, D. E.: Observations of $\mathrm{OH}$ and $\mathrm{HO}_{2}$ radicals over West Africa, Atmos. Chem. Phys., 10, 8783-8801, doi:10.5194/acp-10-8783-2010, 2010.

Eisele, F. L., Mauldin, L., Cantrell, C., Zondlo, M., Apel, E., et al.: Summary of measurement intercomparisons during TRACE-P, J. Geophys. Res., 108(D20), 8791, doi:10.1029/ 2002JD003167, 2003.

Emmerson, K. M. and Evans, M. J.: Comparison of tropospheric gas-phase chemistry schemes for use within global models, Atmos. Chem. Phys., 9, 1831-1845, doi:10.5194/acp-9-1831-2009, 2009.

Gerbig, C., Schmitgen, S., Kley, D., Volz-Thomas, A., Dewey, K., and Haaks, D.: An improved fast-response vacuum-UV resonance fluorescence CO instrument, J. Geophys. Res., 104(D1), 1699-1704, 1999.

Green, T. J., Brough, N., Reeves, C. E., Edwards, G. D., Monks, P. S., and Penkett, S. A.: Airborne measurements of peroxy radicals using the PeRCA technique, J. Environ. Monitor., 5,
75-83, 2003.

Green, T. J., Reeves, C. E., Fleming, Z. L., Brough, N., Rickard, R. A., Bandy, B. J., Monks, P. S., and Penkett, S. A.: An improved dual channel PeRCA instrument for atmospheric measurements of peroxy radicals, J. Environ. Monitor., 8, 530-536, doi:10.1039/b514630e, 2006.

Hanke, M., Uecker, J., Reiner, T., and Arnold, F.: Atmospheric peroxy radicals: ROXMAS, a new mass-spectrometric methodology for speciated measurements of $\mathrm{HO}_{2}$ and $\Sigma \mathrm{RO}_{2}$ and first results, Int. J. Mass Spectrom., 213(2-3), 91-99, 2002.

Hastie, D. R., Weißenmayer, M., Burrows, J. P., and Harris, G. W.: Calibrated chemical amplifier for atmospheric $\mathrm{RO}_{\mathrm{x}}$ measurements, Anal. Chem., 63, 2048-2057, 1991.

Hopkins, J. R., Lewis, A. C., and Read, K. A.: A two-column method for long-term monitoring of non-methane hydrocarbons (NMHCs) and oxygenated volatile organic compounds (oVOCs), J. Environ. Monitor., 5(1), 8-13, 2003.

Jaeglé, L., Jacob, D. J., Brune, W. H., and Wennberg, P. O.: Chemistry of $\mathrm{HO}_{\mathrm{x}}$ radicals in the upper troposphere, Atmos. Environ., 35, 469-489, 2001.

Kartal, D.: Characterization and optimization optimisation of a dual channel PeRCA for the investigation of the chemistry of peroxy radicals in the upper troposphere, $\mathrm{PhD}$. thesis, University of Bremen, Germany, 2009.

Kartal, D., Andrés-Hernández, M. D., Reichert, L., Schlager, H., and Burrows, J. P.: Technical Note: Characterisation of a DUALER instrument for the airborne measurement of peroxy radicals during AMMA 2006, Atmos. Chem. Phys., 10, 30473062, doi:10.5194/acp-10-3047-2010, 2010.

Madronich, S. and Calvert, J. G.: Permutation reactions of organic peroxy radicals in the troposphere, J. Geophys. Res., 95, 56975715, doi:10.1029/JD095iD05p05697, 1990.

Martinez, M., Harder, H., Kubistin, D., Rudolf, M., Bozem, H., Eerdekens, G., Fischer, H., Klüpfel, T., Gurk, C., Königstedt, R., Parchatka, U., Schiller, C. L., Stickler, A., Williams, J., and Lelieveld, J.: Hydroxyl radicals in the tropical troposphere over the Suriname rainforest: airborne measurements, Atmos. Chem. Phys., 10, 3759-3773, doi:10.5194/acp-10-3759-2010, 2010.

Mihele, C. M. and Hastie, D. R.: The sensitivity of the radical amplifier to ambient water vapour, Geophys. Res. Lett., 25, 19111913, 1998.

Mihele, C. M., Mozurkewich, M., and Hastie, D. R.: Radical loss in a chain reaction of $\mathrm{CO}$ and $\mathrm{NO}$ in the presence of water: Implications for the radical amplifier and atmospheric chemistry, Int. J. Chem. Kinet., 31, 145-152, 1999.

Monks, P. S.: Gas-phase radical chemistry in the troposphere, Chem. Soc. Rev., 34(5), 376-395, 2005.

Murphy, J. G., Oram, D. E., and Reeves, C. E.: Measurements of volatile organic compounds over West Africa, Atmos. Chem. Phys. Discuss., 10, 3861-3892, 2010, http://www.atmos-chem-phys-discuss.net/10/3861/2010/.

Olson, J. R., Crawford, J. H., Chen, G., Fried, A., et al.: Testing fast photochemical theory during TRACE-P based on measurements of $\mathrm{OH}, \mathrm{HO}_{2}$ and $\mathrm{CH}_{2} \mathrm{O}$, J. Geophys. Res., 109, D15S10, doi:101029/2003JD004278, 2004.

Olson, J. R., Crawford, J. H., Chen, G., Brune, W. H., et al.: A reevaluation of airborne $\mathrm{HO}_{\mathrm{x}}$ observations from NASA field campaigns, J. Geophys. Res., 111, D10301, doi:101029/2005JD006617, 2006. 
Reeves, C. E., Formenti, P., Afif, C., Ancellet, G., Atti, J.-L., Bechara, J., Borbon, A., Cairo, F., Coe, H., Crumeyrolle, S., Fierli, F., Flamant, C., Gomes, L., Hamburger, T., Jambert, C., Law, K. S., Mari, C., Jones, R. L., Matsuki, A., Mead, M. I., Methven, J., Mills, G. P., Minikin, A., Murphy, J. G., Nielsen, J. K., Oram, D. E., Parker, D. J., Richter, A., Schlager, H., Schwarzenboeck, A., and Thouret, V.: Chemical and aerosol characterisation of the troposphere over West Africa during the monsoon period as part of AMMA, Atmos. Chem. Phys., 10, 7575-7601, doi:10.5194/acp-10-7575-2010, 2010.

Reichert, L., Andrés Hernández, M. D., Stöbener, D., Burkert, J., and Burrows, J. P.: Investigation of the effect of water complexes in the determination of peroxy radical ambient concentrations: implications for the atmosphere, J. Geophys. Res., 108(D1), 4017-4032, 2003.

Salisbury, G., Monks, P. S., Bauguitte, S., Bandy, B. J., and Penkett, S. A.: A Seasonal Comparison of the Ozone Photochemistry in Clean and Polluted Air Masses at Mace Head, Ireland, J. Atmos. Chem., 41, 163-187, 2002.

Sander, S. P., Finlayson-Pitts, B. J., Friedl, R. R., Golden, D. M., Huie, R. E., Keller-Rudek, H., Kolb, C. E., Kurylo, M. J., Molina, M. J., Moortgat, G. K., Orkin, V. L., Ravishankara, A. R. and Wine, P. H., JPL Publication, 06-2, 2006.

Sandu, A. and Sander, R.: Technical note: Simulating chemical systems in Fortran90 and Matlab with the Kinetic PreProcessor KPP-2.1, Atmos. Chem. Phys., 6, 187-195, doi:10.5194/acp-6187-2006, 2006.

Saunders, S. M., Jenkin, M. E., Derwent, R. G., and Pilling, M. J.: Protocol for the development of the Master Chemical Mechanism, MCM v3 (Part A): tropospheric degradation of nonaromatic volatile organic compounds, Atmos. Chem. Phys., 3, 161-180, doi:10.5194/acp-3-161-2003, 2003.

Schlager, H., Konopka, P. Schulte, P., Schumann, U., Ziereis, H., Arnold, F., Klemm, M., Hagen, D., Whitefield, P., and Ovarlez, J.: In situ observations of air traffic emission signatures in the North Atlantic flight corridor, J. Geophys. Res., 102, 1073910750, 1997.
Schulte, P., Schlager, H., Schumann, U., Baughcum, S. L., and Deidwig, F.: $\mathrm{NO}_{\mathrm{x}}$ emission indices of subsonic long-range jet aircraft at cruise altitude: In situ measurements and predictions, J. Geophys. Res., 102, 21431-21442, 1997.

Stewart, D. J., Taylor, C. M., Reeves, C. E., and McQuaid, J. B.: Biogenic nitrogen oxide emissions from soils: impact on NOx and ozone over west Africa during AMMA (African Monsoon Multidisciplinary Analysis): observational study, Atmos. Chem. Phys., 8, 2285-2297, doi:10.5194/acp-8-2285-2008, 2008.

Stone, D., Evans, M. J., Commane, R., Ingham, T., Floquet, C. F. A., McQuaid, J. B., Brookes, D. M., Monks, P. S., Purvis, R., Hamilton, J. F., Hopkins, J., Lee, J., Lewis, A. C., Stewart, D., Murphy, J. G., Mills, G., Oram, D., Reeves, C. E., and Heard, D. E.: $\mathrm{HO}_{\mathrm{x}}$ observations over West Africa during AMMA: impact of isoprene and $\mathrm{NO}_{x}$, Atmos. Chem. Phys., 10, 9415-9429, doi:10.5194/acp-10-9415-2010, 2010.

Tyndall, G. S., Cox, R. A., Granier, C., Lesclaux, R., Moortgat, G. K., Pilling, M. J., Ravishankara, A. R., and Wallington, T. J.: Atmospheric chemistry of small organic peroxy radicals, J. Geophys. Res., 106, 12157-12182, 2001.

Volz-Thomas, A., Lerner, A., Pfitz, H. W., Schultz, M., McKenna, D. S., Schmitt, R., Madronich, S., and Röth, E. P.: Airborne measurements of the photolysis frequency of $\mathrm{NO}_{2}$, J. Geophys. Res., 101(D13), 18613-18627, 1996.

Zenker, T., Fischer, H., Nikitas, C., Parchatka, U., Harris, G. W., Mihelcic, D., Muesgen, P., Paetz, H. W., Schultz, M., VolzThomas, A., Schmitt, R., Behmann, T., Weissenmayer, M., and Burrows, J. P.: Intercomparison of $\mathrm{NO}, \mathrm{NO}_{2}, \mathrm{NO}_{\mathrm{y}}, \mathrm{O}_{3}$ and $\mathrm{RO}_{\mathrm{x}}$ measurements during the OCTA campaign 1993 at Izaña, J. Geophys. Res., 103(D11), 13615-13634, 1998.

Ziereis, H., Schlager, H., Schulte, P., van Velthoven, P., and Slemr, F.: Distributions of $\mathrm{NO}, \mathrm{NO}_{\mathrm{x}}$, and $\mathrm{NO}_{\mathrm{y}}$ in the upper troposphere and lower stratosphere between 28 and $61^{\circ} \mathrm{N}$ during POLINAT 2, J. Geophys. Res., 105, 3653-3664, 2000. 